atha grahāṇāṃ dṛgadhyāyo nirūpyate | tatra dṛṣṭiprayojanam uktaṃ tājikālaṃkāre |

nabhaścarānām na proktam yā vad vīkșaṇalakșanam |

tāvan na śakyate vaktum phalạ̣ varșe śubhāśubham || iti |

yogasudhānidhāv api |

prāpye kareṇāpy akhile 'rthajāte purogate bhrāmyati drșțihīnaḥ |

tathopadișteștaphale vinekșanam vadāmi drștyānayanam tato 'ham || iti |

tatra grahāṇāṃ caturdhā dṛșṭị | ekā pratyakṣasnehā samastalokasamakṣaṃ snehadā | dvitīyā guptasnehā apratyakșasnehakārikā akathitam eveștakāryasaṃsiddhidā | tṛtīyā guptavairā aprakāśitaśatrubhāvakārikā| caturthā 10 pratyakṣavairā | āsāṃ lakṣaṇaṃ dṛșțiparimāṇam cāha samarasiṃhaḥ |

navapañcamayor drșțịh pādonā sarvadrștitah sabalā | melāpakadrșțir iyam pratyakșasnehadrștiśs ca \| tārtīyaikādaśayor drșțau yo vīkșate trttīyadrśā taddrștis tryamśonānyasya tu șaḍhāgadrșțiś ca| anayor guptasnehā drsțtị sarvatra kāryasiddhikarī $\mid$

6 prāpye] prāpte K T M 13 sneha] snehada N 14 tārtīyaikā-] tṛtīyaikā- G p.c. T

6-7 prāpye ... 'ham] TYS 5.1

12-162.5 nava ... syuh] These stanzas by Samarasimha have been preserved in PT 4.49-51 and reworked in ST 2.9-10.

(C) MARTIN GANSTEN, 2020 | DOI:10.1163/9789004433717_004

This is an open access chapter distributed under the terms of the GC BY 4 -olicense. 


\section{Aspects and Dignities}

\section{The Various Aspects and Their Results}

Now the chapter on the aspects of the planets is set forth. Regarding that, the purpose of aspects is declared in the Täjikālaṃkāra:

Until the characteristics of the aspects of the planets have been described, it is not possible to predict the good and evil results of a year.

And in [Tājika]yogasudhānidhi [5.1]:

Even with every object in front of him within arm's reach, a man bereft of sight stumbles; so also when the results sought [by astrology] are taught without the aspects; therefore I shall explain the calculation of aspects. ${ }^{1}$

On that matter, the planets have four kinds of aspect. One is openly friendly, [that is], it displays friendship before the eyes of all the world. The second is secretly friendly, [that is], its friendship is not given openly: it perfects the matter sought without announcing it. The third is secretly inimical: it causes undivulged conditions of enmity. The fourth is openly inimical. Samarasimha states their characteristics and the extent of aspects [in the Tājikaśāstra]:

The aspect on the ninth and fifth [signs] is strong, less than a full aspect by a quarter. This is an aspect of uniting and an aspect of open friendship. In an aspect on the third and eleventh [signs, the planet] that aspects with the aspect on its third has an aspect less [than full] by a third; the other [planet] has an aspect of one sixth. Their aspect is one of secret friendship and perfects every matter. ${ }^{2}$

1 A pun on the word $d r s t ̦ i$, which means 'sight' in the everyday sense as well as an astrological aspect.

2 The numbers of the aspected signs are all reckoned inclusively, the sign occupied by the aspecting planet being considered the first. 
anyasyaikādaśasyātra drașțuḥ |

daśamacaturthā drsțịh pādadrg iha guptadurjanākhyā tu |

yātobhayasaptamake sakalā pratyakșadurjanā drșțiḥ \|

ekarkșasthitayor apy ubhayor drșțir matā sakaladrșțị| |

sāpy ubhayasaptamanibhā tisro 'ridrśa ḥ̣ kṣutākhyāḥ syuh || iti |

viśadaṃ dṛșțiphalam āha vāmanaḥ |

pañcame navame dṛsțị sarvasaukhyaphalapradā |

prakațīkurute hy eșā mitrāṇi svajanāms tathā $\|$

tritīyaikādaśe drșțị sadā snehapravardhinī|

sutasaṃtoșadā bhavyā hy āyurvrddhidhanapradā $\|$

caturthe daśame drștir guptadurjanabhedikā |

mitraghātakarì duștāa śokasaṃtāpavardhinī||

ubhayoḥ saptamā drsțtih prakațā ripubhedin̄̄|

vivādam vigraham yuddham jhakațam ca karoti hi $\|$

ekarkșe balinī drșțị prādhānyāt kāryasādhin̄ |

svasthāne phaladā jñeyā mitrapakșāt tathaiva ca \|

trtīiaikādaśe pādam dalam vyomacaturthayoḥ|

trikoṇe tryañghri mūrtyaste pūrṇam paśyanti khecarāḥ || iti |

tājikasāre 'pi

pādaṃ trirudre svadalam khaturye pādatrayaṃ syān navapañcame 'pi $\mid$ paśyanti pūrnam samasaptake ca grahā na cānyatra vilokayanti || iti |

1 anyasyaikā-] anasyaikā- K || -daśasyātra] -daśasyānna N; -daśasthānna G; -daśasthāna K T M; || drașțuh] dṛșțaḥ N; dṛștuh G T; drașțuh K M; $\quad 2$ caturthā] caturthe K T M 3 yātobhaya] yā cobhaya K T M 4 sakaladṛștịh] sakalā 6o dṛșți N G; sakalā 6o dṛștiś ca K T; sakalā 6o || dṛ̦țiś ca M 5 sāpy ubhaya] sā ubhaya T M \| saptamanibhā] saptakhāmbuni

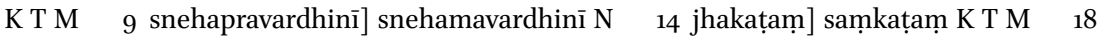
mūrtyaste] mūrtyasthe K T; mūrtisthe M 20 svadalaṃ] sadalam B N G 21 na] nya T

20-21 pādaṃ ... vilokayanti] TS 57

$18 \mathrm{iti}$ ] At this point K T M insert the following sentence with minor variations: atra vāmanena trtīye tryamśonā 40 ekādaśe (ekādaśame $\mathrm{K}$ ) șaḍhhā (șaḍhhāh M) 10 gamitā caturthadaśame pādamitā 15 drșțir uktā tatra mūlabhūtasya samarasiṃhasya viruddhād vānekatājikagraṃthādau mūlaṃ mrgyam iti. 
Here, 'the other [planet]' is the one that aspects its eleventh. [Continuing from the Tãjikaśāstra:]

The aspect on the tenth and fourth here is a quarter-aspect and is called [that of] a secret enemy; and that aspect which goes to the seventh [sign] of both [planets] is full, [the aspect of] an open enemy. When both [planets] are in one sign, that aspect too is considered a full aspect; it is similar to the mutual [aspect on] the seventh. [These] three inimical aspects are called $k s ̦ u t a .^{3}$

Vāmana explains the results of aspects clearly:

The aspect on the fifth and ninth gives as its result all [sorts of] happiness; for it manifests friends and one's own people. The aspect on the third and eleventh always increases friendship; it is pleasant and gives children and contentment, ${ }^{4}$ increase of longevity and wealth. The aspect on the fourth and tenth signifies secret enemies; it is evil, causes injury from friends, ${ }^{5}$ and increases sorrow and suffering. The mutual seventh aspect signifies open enemies, for it causes disputes, conflicts, fighting and quarrels. The aspect in a single sign is strong and most effectively accomplishes a matter. It is understood to give results in [one's] own place or by means of friends. Planets aspect the third and eleventh [signs] by a quarter, the tenth and fourth by half, a trine by three quarters, and the first and seventh fully. ${ }^{6}$

And in Tājikasāra [57 it is said]:

A quarter on the third and eleventh; half on the tenth and fourth; three quarters on the ninth and fifth; and the planets aspect the same [sign] and the seventh fully, but do not aspect any other.

3 The word $k s ̦ u d$ - or kșuta-drsțti, which recurs in several Tājika texts, is of uncertain derivation, although the general meaning of 'evil aspect' is clear. For a discussion of Samarasimhha's aspect doctrine and its relation that of Sahl ibn Bishr, see the Introduction and Gansten 2018.

4 Or: 'contentment with children'.

5 Or: 'injury to friends'.

6 A trine in this sense (trikona) means the fifth or ninth sign or house. 
atraikarkṣe samarasiṃhenāśubhā dṛ̦țir uktā vāmanena śubhā dṛștị uktā | anayor vākyayor vyavasthā | yau grahāv ekasthānagatau tau uccasvagṛhagatau vakșyamāṇamaitrīcakreṇa prakārāntareṇa vā mitragṛhagau vā syātām tayor dṛșțị śubhaphaladātrī | yadā tu samaśatrunīcakṣetrādigau syātāṃ tadā tayor dṛșțir aśubheti ||

atha samarasiṃhena caturthadaśame pādadṛștir uktā | tṛtīye tryamśonā ekādaśe șaḍbhāgadṛșțir uktā | vāmanena haribhaț̣ena caturthadaśame 'rdhadṛștis tṛtīyaikādaśe pādadựțtir uktāsti | tatra ṛ̣isthānābhiṣiktasamarasiṃhavirodhād vāmanādivākye mūlaṃ mṛgyam ||

atha yavananāmānikitā dṛ̦țị̣ |

mukārināa syād ekarkșe saptame syān mukāvilā| taravī dikcaturthe tu tisrậ proktā bhayapradāḥ || trtīyaikādaśe dṛștis tasdī proktā mahottamā | navapañcamayor drșțis taślī proktā mahāśubhā || iti |

atha drașț̣̣̣̂̂́yayo rāśibhede saty api dvādaśāmśamadhye tayor avasthāne dṛștayo yathoktaphaladātryaḥ syuh | dvādaśāṃśātikrame tu sādhāraṇaphaladātryaḥ syur ity uktaṃ samarasiṃhena|

2 vyavasthā] vyaśvāsthā $\mathrm{B}$ N G a.c. \| tau] om. K T 3 syātām] tadā add. G K T $\quad 6-9$ atha ... mṛgyam] om. B N G a.c. K T M 10 yavananāmāṅkitā] yavananām aṃgīkṛtā G p.c. $\quad 11$ saptame] saptabhe T M 12 dik] dṛk B N G T 13 tṛtīyaikādaśe] tṛtīyaikādaye N G \| tasdī] ta dā K; tadā T M 14 pañcamayor] pañcayor T $\|$ dṛsțis taślī] dṛsțis tallī G p.c.; dṛsțiir va lī K;

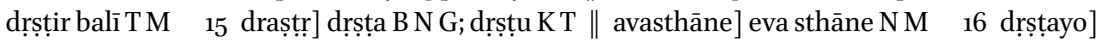
dṛșțayor K T || -dātryaḥ syuḥ] -dātryo M 17 phaladātryaḥ] phaladā ạ̣ G a.c.

6-9 atha ... mrgyam] This passage, found only in G as a correction inserted in a different hand, appears to be a fuller and more coherent version of the sentence added by $\mathrm{K}, \mathrm{T}$ and M immediately prior to the foregoing quotation. 13-14 tṛtīyaikādaśe ... mahāśubhā] The conspicuous spaces in K may suggest an intermediate stage where the initial elements of conjunct characters have been eliminated with some hesitance from the Sanskritized Arabic terms tasdī and taślī to form recognizable, if superfluous, Sanskrit lexemes. 17 phaladātryah] The reading of $\mathrm{G}$ is another instance of confusion of the characters $a$ and trya in northern-style Devanāgarī. 
Here, Samarasimha declares the aspect in the same sign to be evil; [but] Vāmana declares it to be a good aspect. The verdict on [the matter of] these two statements [is this]: if two planets are in one place and they occupy their exaltation or domicile, or the domicile of a friend according to the table of friendships described below or by some other method, then their aspect will yield good results. But when they should occupy a neutral or inimical sign, their fall, and so on, then their aspect is evil. ${ }^{7}$

Also, Samarasimha declares the aspect on the fourth and tenth [signs] to be a quarter aspect [in strength]; that on the third is said to be less [than full] by a third, and the aspect on the eleventh to be one sixth [in strength]. [But] Vāmana and Haribhațta declare half an aspect on the fourth and tenth and a quarter aspect on the third and eleventh. In that regard, since they conflict with [the statement of] Samarasimha, who is anointed to the rank of a sage, the basis of the statements by Vāmana and others is questionable. ${ }^{8}$

Next, [each] aspect called by its Yavana name: ${ }^{9}$

It is mukārinā in one sign, mukāvilā on the seventh, and the aspect on the tenth and fourth is taravi: [these] three are said to bring danger. The aspect on the third and eleventh, called tasdi, is most excellent; the aspect on the ninth and fifth, called taślī, is greatly auspicious.

Now, even when the aspecting and the aspected [planet] are in different signs, ${ }^{10}$ while they remain within a distance of twelve degrees, their aspects give the results described; but when they pass beyond twelve degrees, they give [only] ordinary results. So says Samarasiṃha [in the Täjikaśāstra]:

Although Dykes (2019a: 51) interprets the Arabic text of Sahl as including only the opposition among the inimical aspects, both the Indian translator (Samarasimpha?) and the unknown medieval Latin translator appear to have taken it to include the conjunction; see Gansten 2018.

8 Nevertheless, Balabhadra's own 'easy method' of calculating aspect values in section 2.3 below is based on the ratios given by Vāmana and Haribhațta, rather than those of Samarasiṃha and Nīlakaṇțha.

9 The source of this stanza is unknown, but it is likely to be a quotation. See the Introduction and Gansten 2018.

10 This presumably means different from the signs forming the aspect angle under consideration. For instance, Cancer forms a square with Aries, being $90^{\circ}$ distant from it, whereas Leo forms a trine $\left(120^{\circ}\right)$ with Aries; but a planet at the very end of Aries will still form a square with a planet at the very beginning of Leo, as they are within a $12^{\circ}$ margin of the $90^{\circ}$ angle. 
sarvāś caitā hi driśo dvādaśabhāgāntare bhaveyuś cet | tat saviśsșā jñeyā drștyanusārāt phalaṃ sarvam || iti |

vāmano'pi |

dṛștisthāneșu sarveșu dvādaśāṃśāntare sthitah |

śighragrahād graho mandạ̣ śubhā sā drșțir ucyate || iti |

atra grahānāạm dīptāṃśamadhye dṛ̣țiphalam pūrṇam ity uktam tājikaratnamālāyām |

dīptabhāgasthitāḥ santo dṛ̦țisthāneșu cet sthitāḥ| tadā drștiphalam pūrṇam proktam yacchanti khecarāḥ || iti |

saṃjñātantre 'pi |

puraḥ prșțhe svadīptāṃśair viśișțaṃ dṛkphalam grahaḥ|

dadyād atikrame teșām madhyamam dṛkphalam viduh || iti |

viśeșo muktāvalyām |

śïghrakhecarapurah sthiragāmì tasya dṛn nigaditādyaphalā sā|

anyathā bhavati bhāviphalāptyai vartamānaphaladā samagatyā || iti |

anyo viśeșas tājikasāre |

krüragrahāś cet khaladrșțisaṃsthāḥ

pāpetarāh saumyadrśi sthitāś ca|

yacchanti te drștiphalam yathoktam

phalam tadardham ca vilomasamsthāh || iti |

2 saviśeșā] saśeșā B N G a.c. || phalaṃ] om. M 5 ucyate] uttamā B N G a.c. 10 'pi] om. K T M 14 nigaditādyaphalā sā] scripsi; nigaditāccaphalāsaā B; nigaditāccapalāṃ N; nigaditāccaphalāṃśā G; nigaditā viphalā sā K T M 15 phalāptyai] phalāptau B N G K 16 anyo] anyopi $\mathrm{T} \quad 20$ tadardham] tadardhe $\mathrm{T}$

11-12 puraḥ ... viduh] ST 2.14 14-15 śīghra ... samagatyā] TM $44 \quad$ 17-20 krūra ... saṃsthāḥ] TS 61

1-2 sarvāś ... sarvam] This stanza by Samarasiṃha has been preserved in PT 4.52. 14 nigaditādyaphalā sā] The emendation is supported by Ms TMi. 
For if all these aspects occur within twelve degrees, then they should be known to be particular[ly effective]. All results [come to be] in accordance with the aspects.

And Vāmana [says]:

[If] the slower planet is situated within twelve degrees of the faster planet in any place of aspect, that aspect is called good.

Concerning this, it is said in the Tājikaratnamālā that the results of an aspect [occurring] within the orbs of light of the planets are full:

If occupying the places of aspect while placed within the orb of light, the planets give the declared results of the aspect in full.

And in Samjjñātantra [2.14 it is said]:

A planet gives the particular results of its aspects within its own orb of light, in front and behind; beyond it, the results of the aspect are known as middling.

A special rule [is stated] in [Täjika]muktāvali [44]:

[If] the slow-moving [planet] is ahead of the faster planet, the result of its aspect is said to be in the past; if the reverse, the result will be accomplished in the future; if their position [in degrees] is the same, [the aspect] gives results in the present. ${ }^{11}$

Another special rule [is stated] in Tājikasāra [61]:

If malefic planets occupy [the places of] malefic aspects, and benefics occupy [the places of] benefic aspects, they give the results of the aspects as declared; but [only] half those results if conversely placed.

11 As seen from the discussion in section 3.3 below, the word 'ahead' (puras, which can also mean 'easterly') must be understood in the sense of the daily motion of the planets (from rising in the east to culminating in the south, etc.) for this statement to harmonize with the other Tajika (and Arabic-language) teachings on aspects. The principle is typically expressed in the opposite manner: the slower-moving planet being ahead of the faster-moving one in the zodiac, so that the aspect is approaching perfection, is considered to signify a future event. 
yadā tu krūrāḥ saumyadṛștiviṣaye saumyāḥ krūradṛștiviṣaye tadārdhaphaladātāraḥ syuḥ | krūrasaumyayor yoge caraṇatrayaṃ phalaṃ jñeyam | yad āha vāmanaḥ |

duștadrștisthitāḥ krūrāḥ saumyāḥ saumyadrgāśritāḥ| drștyudbhavam phalam pūrṇaṃ nụnām yacchanti khecarāh \| vyatyayasthāh phalasyārdham yacchanti grahadrșțijam | pādonam saumyapāpaiś ca phalam jñeyam vicakșaṇaị̣ || iti |

viśeșāntaram āha samarasiṃhah | cakrasya vāmadrșțer dakșinadr̦șțir balīyasī jñeyā | iti | atra cakrasya vāmadakșiṇalakșaṇam uktaṃ hillājena |

dyūnāe ca rāsiș̣aṭaṃ bāhyākhyaṃ cāntaraṃ lagnāt | bāhyābhyantarayor api saṃjñoktā vāmadakșinākhyā tu \|

vāmano 'pi |

cakrādyantadale drșțir grahānāạn vāmadakșiṇā|

jñeyaṃ tābhyāṃ bale prauḍa à vāmadrșțes tu dakșiṇa || iti |

9 cakrasya] cakramya B || vāmadṛ̦țer] vāmadṛșțir N a.c. G a.c. || balīyasī] balīyasāṃ G 14 cakrādyantadale] scripsi; cakrādyaṃtarddale B N G; cakrādyanārdale K; cakrādyamnnārdale T; cakrādyānāṃ dale M 15 dṛștes] dṛște N G; dṛțțais T M

9 cakrasya ... jñeyā] According to PK ad ST 2.13, the next quotation from Samarasiṃha constitutes the remaining half of this stanza. The present half-stanza recurs in KP 2.13 with the variant reading $t v \bar{a} s ́ u$ for jñeyā. 
But when malefics are within the scope of benefic aspects, and benefics within the scope of malefic aspects, then they give half their [expected] results. When they are configured with [both] a malefic and a benefic, the results should be understood to be three quarters [full]. As Vāmana says:

Malefic planets occupying [the places of] malefic aspects, and benefics occupying [the places of] benefic aspects, give men the results produced by the aspects in full. Contrarily placed they give half the results of the planets' aspects; [if they are aspected] by [both] benefics and malefics, the results should be understood by the wise to be less [than full] by one quarter.

\subsection{Dexter and Sinister Aspects}

Samarasiṃha states another special rule [in the Tãjikaśāstra]:

A right-hand aspect in the circle should be known to be stronger than a left-hand aspect. ${ }^{12}$

Concerning this, a definition of the left and right of the circle is given by Hillāja:

The six signs [counted] from the descendant are called exterior, and [the six signs counted] from the ascendant are interior. [Another] designation for the exterior and interior is left and right, [respectively]. ${ }^{13}$

And Vāmana [says]:

The aspects of the planets on the former and latter half of the circle are left and right, [respectively]. Of the two, the right one should be understood to be greater in strength than the left.

12 For the distinction between dexter and sinister aspects, which goes back to Hellenistic sources but is not found in classical Indian astrology and is misunderstood in the Tajika tradition (including the present work), see the Introduction and Gansten 2018.

13 The phrase 'six signs' should be understood in the sense of $180^{\circ}$ counted from the degree of the descendant to that of the ascendant or vice versa. 
ayam arthaḥ | lagnasthagrahasya lagnasya bhogyabhāgād ārabhya saptamabhuktabhāgaparyantam yāvad dụștị sā dakṣinā | evaṃ saptamāl lagnaṃ yāvad vāmadṛștị | sā dakṣiṇadṛștyapekșayā nirbalā jñeyeti | udāharaṇam āha samarasiṃhaḥ|

\section{bhūkendropari drsțir madhyāt sabaleti sarvatra | iti |}

asyārthah | daśamadṛșteh sakāśād bhūkendropari yā dṛ̦̣țị̣ sā sabalā evaṃ sarvatra jñeyam | ayam arthạ | daśamasthagrahasya caturthaparyantam yā dṛștịh sā dakșinadựștitvāt sabalā | ataś caturthād daśamaṃ yāvad vāmadṛș̣itvān nirbalā ity arthah \||

sthānaviśeșoktadṛsțter viśeșaphalanirṇayārtham spașțadṛșțikalānayanam 10 uktam samjjñātantre |

1 bhogya] bhukta B N G 2 saptamāl] saptamāc ca K T M 3 dakṣiṇa] dakṣināā K || nirbalā] sabalā G p.c. K T M $\quad$ 4-6 samarasiṃhạ̣ ... asyārthaḥ] om. B N G a.c. $\quad$ 7-9 ayam ... arthaḥ] om. K T M 10 nirṇayārthaṃ] nirṇayārthe M || kalānayanam] kālānayanaṃ G

5 bhū ... sarvatra] PK ad ST 2.13 quotes the same half-stanza from the now lost foundational work by Samarasiṃha, reading sarvato 'py ühyam for sarvatra. $\quad$ 7-9 ayam ... arthah] In place of this passage, K T M insert a wholly different one which may or may not have originated with Balabhadra, but in its present form appears to contradict the reasoning in the surrounding passage: yathā saptamasthagrahasya lagnād (lagnā K) daśame caturthe ca pādamitā drșțir asti parantu caturthadrșțir vāmadrsțittvād daśamadakșināa (dakșiṇa T) drștyapekșayā itthaśálādiyogeșv anyayogeșv api vā sabalā jñeyeti atha. With nothing on which to base an emendation, I have chosen not to include it in the main text. The accepted reading, being an explication of the quotation from Samarasimha and attested by the older witnesses, does seem likely to belong to Balabhadra's text proper, although it is curious that the text witnesses that retain it have omitted the quotation itself - an omission later corrected in the case of G.

14 'The angle of the earth' means the anti-culminating point or lower midheaven, where the ecliptic intersects the meridian below the horizon. The tautological reading 'tenth 
The meaning is as follows: for a planet placed on the ascendant, an aspect in the space beginning from the degree about to be traversed by the ascendant and ending with the degree [last] traversed by [the cusp of] the seventh house is a right-hand one. Likewise, a left-hand aspect [is found] in the space from the seventh [cusp] to the ascendant; and that should be understood to be weaker compared to a right-hand aspect. Samarasimpha gives an example [in the Tãjikaśāstra]:

An aspect on the angle of the earth from the midheaven is strong: it is so in all cases.

That means: an aspect [that goes] from the region of the tenth aspect [and falls] on the angle of the earth is strong, and it should be understood likewise in all cases. ${ }^{14}$ The meaning is as follows: an aspect of a planet occupying the tenth [house], ending in the fourth [house], is strong by virtue of being a right-hand aspect. Therefore, [the aspect that occurs] in the space from the fourth [house] to the tenth is weak by virtue of being a left-hand aspect: this is meant. ${ }^{15}$

\subsection{Numerical Values of the Aspects}

The calculation of the exact [strength of an] aspect in points, to determine the particular result of an aspect to a particular place as described [above], is described in Samjñ̄attantra [2.11-12]:16

aspect', though present in all text witnesses, is probably a mistake for something like 'tenth house' or 'tenth cusp'. In this case the quoted source is clearer than the gloss provided to explain it! As the contents of this sentence are more or less repeated in the following two, the former may conceivably have been quoted or paraphrased from a commentary on the Tãjikaśāstra.

15 By the original definition of the terms, an opposition can be neither dexter nor sinister: the distinction is applied only to the aspect angles formed in two opposite directions by the same planet (trines, squares and sextiles). The underlying idea seems to be that, in an aspect between two planets, the one that would already be above the horizon as the other was rising in the east holds the dominant position. In an opposition, both planets will be at the horizon simultaneously: one in the east, the other in the west.

16 Here and throughout the following discussion of planetary strength, the word kalā, which in other contexts means a minute of arc, is translated as 'point'. The maximum strength is typically 6o points, which make up 1 rüpa or 'unit' of strength. The exception is the viṃsopaka or 'twenty-point' scheme, where values are divided by 3 to make a maximum score of 2o. Occasionally, however, vimssopaka is used more loosely to mean 'point' in general. 
apāsya paśyam nijadríyakhețād

ekādiśeșe dhruvaliptikāh syuḥ|

pūrṇaṃ khavedās tithayo 'kṣavedāh

kham șaștir abhram śaravedasaṃkhyāh \|

tithyạ khacandrā viyad abhratarkāh

śsẹāmśayātaișyaviśsșaghātāt |

labdham kharāmair adhikonakaisye

svarṇam dhruve tāḥ sphuțadrșțiliptāḥ || iti |

\begin{tabular}{lll}
\hline rāśayạ̣ & dṛștikalāh & antaram \\
\hline 0 & 60 & $60 \mathrm{r}$ \\
1 & 0 & $40 \mathrm{dha}$ \\
2 & 40 & $25 \mathrm{r}$ \\
3 & 15 & $30 \mathrm{dha}$ \\
4 & 45 & $45 \mathrm{r}$ \\
5 & 0 & $60 \mathrm{dha}$ \\
6 & 60 & $60 \mathrm{r}$ \\
7 & 0 & $45 \mathrm{dha}$ \\
8 & 45 & $30 \mathrm{r}$ \\
9 & 15 & $5 \stackrel{r}{ }$ \\
10 & 10 & $10 \mathrm{r}$ \\
11 & 0 & $60 \mathrm{dha}$
\end{tabular}

4 khaṃ] khe K M 9 dṛsțikalāḥ] scripsi; dṛștidgalma B; om. G; dṛșțika K; vṛścika T M 12 40] 4 K T M 195 r] 15 r B G a.c.; 5 dha K T M $2010^{2}$ ] o K T M

1-8 apāsya ... liptāḥ] ST 2.11-12

9 rāśayah] The following table is omitted by $\mathrm{N}$. 
Subtracting [the longitude in signs and so forth of] the aspecting [planet] from [that of] the one it aspects, for the remainder of one and so forth the constant value in points is nil, forty, fifteen, fortyfive, nil, sixty, nil, forty-five, fifteen, ten, nil [and] sixty, [respectively]. Multiplying the difference between the previous and the following [value] by the remaining degrees and dividing by thirty, [one should] add to or subtract from the constant accordingly as the constant being approached is greater or less: that [result] is the exact [value of the] aspect in points. ${ }^{17}$

\begin{tabular}{lll}
\hline Signs & Aspect points & Difference \\
\hline 0 & 60 & -60 \\
1 & 0 & +40 \\
2 & 40 & -25 \\
3 & 15 & +30 \\
4 & 45 & -45 \\
5 & 0 & +60 \\
6 & 60 & -60 \\
7 & 0 & +45 \\
8 & 45 & -30 \\
9 & 15 & -5 \\
10 & 10 & -10 \\
11 & 0 & +60 \\
\hline
\end{tabular}

17 The constant values are simply the point values assigned to the aspects in Samarasimhha's scheme. The modification introduced here, if taken literally, will sometimes result in a separating aspect (where the distance from the exact aspect angle is increasing) being considered stronger than an applying aspect (where the distance is decreasing), or in an applying aspect being considered stronger than an exact one, which contrasts sharply with Perso-Arabic practice. 


\begin{tabular}{|c|c|c|c|}
\hline $\begin{array}{l}\text { drașțrā } \\
\text { varjitadṛ́śyah }\end{array}$ & $\begin{array}{l}\text { śeṣabhāga- } \\
\text { guṇakāḥ }\end{array}$ & bhājakāḥ & $\begin{array}{l}\text { pātyāḥ } \\
\text { kalāḥ }\end{array}$ \\
\hline 10 & 1 & 2 & 15 \\
\hline 2 & 1 & 2 & 15 \\
\hline 3 & 1 & 1 & $3^{\circ}$ \\
\hline 9 & 1 & 1 & 30 \\
\hline 4 & 3 & 2 & 45 \\
\hline 8 & 3 & 2 & 45 \\
\hline O & 2 & 1 & 60 \\
\hline 6 & 2 & 1 & 60 \\
\hline \multicolumn{4}{|c|}{ sthānadvaye samarasiṃhamatena dṛṣṭị̣ } \\
\hline 2 & 4 & 3 & 40 \\
\hline 10 & 2 & 6 & 10 \\
\hline
\end{tabular}

athātra sugamopāyo matkṛtah |

drașțrā vihīnadṛśyasya śeșato dṛștir ucyate |

ekaśeșe vinā rāśim aṃśārdhaṃ dṛșțir ucyate ||

dvibhe pañcadaśopetaṃ bhāgārdhaṃ ca triśeșake |

bhāgārdhaṃ triṃśatā yuktam caturbhe svārdhasamyutāh ||

bhogyāṃsāḥ pañcabhe dvighnā bhuktāṃśā dṛṣṭir ucyate |

ṣaḍbhe dvighnā bhogyabhāgāḥ saptabhe svārdhasaṃyutāḥ ||

bhuktabhāgā bhaved dṛșṭị kalādyā tājikoditā |

așțabhābhyadhikaṃ prohya rāśyādyaṃ bhavarāśitạ̣ ||

\footnotetext{
1 drașțrā] scripsi; dṛșțā B; dṛștạ G; dișțā K T M || śeșa] śe B N; roṣa K T || pātyāḥ] pāvā K T M 2 dṛśyaḥ] dṛsāa K T; dṛ́saḥ M || guṇakāḥ] grahāṃkā K; grahakāḥ T; grahāṃkāḥ M 11 sthānadvaye ... dṛsțih ] om. K T M 13 10 $^{1}$ ] scripsi; 6 B G; om. K T M \| 2] 1: K T M \| 6] scripsi; 1 B N; 3: K T M || 10²] scripsi; 6o B G; om. K T M 15 draștrā] scripsi; dṛsțā B N G; dṛșţāa K T M 16 aṃśārdhaṃ] aṃśārdhā M 18 bhāgārdhaṃ] bhāgārddhāt M \| yuktaṃ] yuktaś M \| caturbhe] caturthe K T M \| saṃyutāḥ] saṃyutam K T M 19 dvighnā] pañcame K T M || bhuktāṃśā] bhoktāṃśā K T 20 saptabhe] saptame K T M 22 aștabhā-] aștamāK T M
} 


\begin{tabular}{llll}
\hline $\begin{array}{l}\text { Aspected [planet] minus } \\
\text { aspecting [planet] }\end{array}$ & $\begin{array}{l}\text { Multipliers of } \\
\text { remaining degrees }\end{array}$ & Divisors & $\begin{array}{l}\text { Points to } \\
\text { be reduced }\end{array}$ \\
\hline 10 & 1 & 2 & 15 \\
2 & 1 & 2 & 15 \\
3 & 1 & 1 & 30 \\
9 & 1 & 1 & 30 \\
4 & 3 & 2 & 45 \\
8 & 3 & 2 & 45 \\
0 & 2 & 1 & 60 \\
6 & 2 & 1 & 60 \\
\hline
\end{tabular}

Aspects on two places according to the opinion of Samarasimpha:

\begin{tabular}{llll}
2 & 4 & 3 & 40 \\
10 & 2 & 6 & 10 \\
\hline
\end{tabular}

Next, an easy method for this, devised by myself:

The [strength of an] aspect is said to be [derived] from the remainder when the aspecting [planet] has been subtracted from the aspected one. When the remainder [in signs] is one, the aspect [value] is said to be half the degrees, excluding the sign. When it is two signs, [the aspect value is] half the degrees with fifteen added. When the remainder is three [signs, the aspect value is] half the degrees added to thirty. When it is four signs, [the aspect value is] the degrees left [till the end of a thirty-degree increment] added to half of the same. When it is five signs, the aspect [value] is said to be twice the degrees elapsed [in the thirty-degree increment]; when it is six signs, twice the degrees left. When it is seven signs, the exceeding degrees added to half of the same become the aspect [value] in points and fractions proclaimed by the Tājikas. Above [and including] eight signs, [the values of] the signs and so forth should be counted conversely from the eleventh sign: ${ }^{18}$ the

18 This convoluted instruction means that the value of a remainder of 11, 10, 9 or 8 signs equals that of 1, 2, 3 and 4 signs, respectively; but the fractions are subtracted from the whole values rather than added to them. 
śeșam aṃśîrụtaṃ dvābhyāṃ hṛtam dṛșțis tu jāyate | navabhe daśabhe 'py evam śivabhe bhuktabhāgakāh | dvinighnā śūnyabhe dvighnā bhogyāṃśā dṛștiir ucyate ||

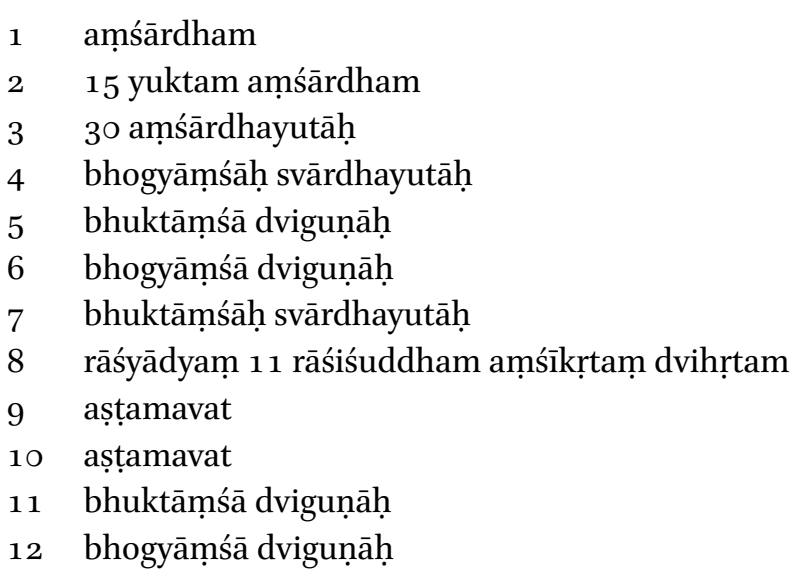

athāsmin dṛ̦țigaṇite sthānadṛ̦̣tịm vināpi grahāṇāṃ dṛ̦țir āyāti | tad yathā | dṛśyo bhaumah 5|15 drașțā candraḥ o|5 | atrobhayor yady api șașțhāștame sthānadṛștịir nāsti tathāpi pūrvoktaganitenāgatā dṛșțikalāḥ 20 | tatra vakșyamāṇetthaśālādiyoge varșeśavicāre ca atha ca yo bhāvaḥ svāmisaumyābhyām dṛsțo yukto 'yam edhate ityādibhāvavicāre ca sthānadṛțteh prāmāṇyaṃ gaṇitāgatadṛțter vā | iti saṃśayanivāranāārtham yathobhayor aikyam bhavati tathā dṛ̦țigaṇitam uktaṃ muktāvalyām |

2 navabhe] navame K T M $\|$ daśabhe] daśame K T M $\quad 515$ yuktam] bhuktam K T M 6 yutāḥ] yuktā G; yutāma K T $\quad 7$ svārdhayutāḥ] tvā atāḥ K T; tvāgatāḥ M 8 bhuktāṃśā dviguṇāḥ] bhuktāṃśādiguṇa K T M 9 bhogyāṃśā dviguṇāḥ] bhogyāṃśādiguṇa K T M 10 svārdhayutāh] svāīgatā K T; svāīgata M 11 11] rā K T; om. M \|| dvihṛtam] dvidane K T; dvidate M 14 bhuktāṃśā dvigunāḥ] bhuktāṃsāādirāṇā K; bhuktāṃśādiguṇa TM 15 bho-

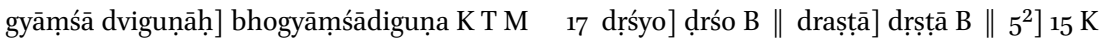
T M 18 gaṇitenāgatā] gaṇitināgatā K $\| 20] 2 \mathrm{~B} ; \mathrm{om}$. N 19 varṣeśavicāre] varṣe śanicāre B || svāmisaumyābhyāṃ] svāmisvāmyābhyāṃ N B a.c.

19-20 yo ... edhate] VT 5.1; BPH 74.10

4 1] The following table is omitted by N. G adds in the margin: rāse drști krtāḥ. 
remainder in degrees, divided by two, become the aspect [value]; similarly when [the remainder] is nine or ten signs. When it is eleven signs, twice the exceeding degrees, and when nil signs, twice the degrees left, are said to be the aspect [value].

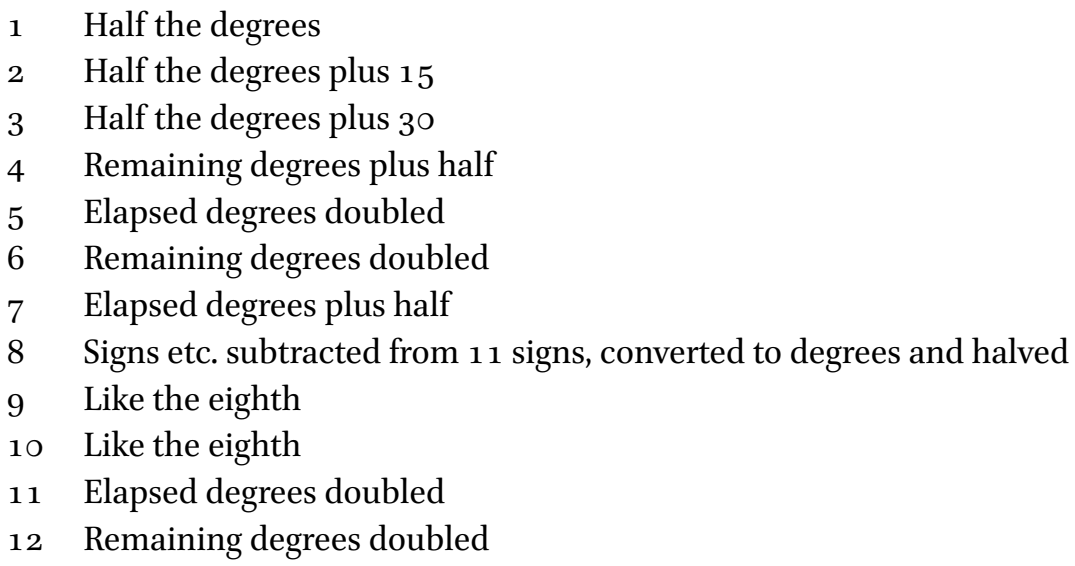

Now, in this calculation of aspects, even without an aspect by place, planets may achieve an aspect. For example, Mars is the aspected [planet at] 5 [signs] 15 [degrees] and the moon the aspecting [planet at] o [signs] 5 [degrees]. ${ }^{19}$ Although there is no aspect by place here, [as the planets are] in the sixth and eighth from each other, still, according to the calculation just described, we get an aspect [strength] of 20 points. That being so, in the itthaśâla and other configurations described below, and in determining the ruler of the year, and also in judging the houses - according to [statements] such as [Varșatantra 5.1:] 'The house that is aspected or joined by its ruler and a benefic prospers' - is it the aspect by place or the aspect derived by calculation that is valid? To remove that doubt so that unity prevails between the two [methods], the calculation of aspects is described thus in [Tājika]muktāvali [40-41]:

\footnotetext{
19 That is, Mars has completed the first 5 signs of the zodiac and is at $15^{\circ}$ Virgo; the moon is at $5^{\circ}$ Aries.
} 
draștrūnadrśye daśadrgbhatulye

bhāgādy adho netrahrtam tithibhyah |

tryanke kharāmebhya ibhäbdhibhe tu

trighnam dvihṛtyāptam ișuśrutibhyạ̣ \|

khatarkarāśipramite dvinighnam

viyadrasebhyo bhavatīha drștih |

śrutīndunighnatrilavo dvidigbhe

khābdhïrakebhyaḥ smarasiṃhaśāstrāt || iti |

atra tṛtīyaikādaśādyuktadṛștisthāneșv eva dṛștigaṇitam uktam nānyasthāneșu | tatrāpi rāśyādāv uktadṛștẹ prārambhah rāśyante ca kṣayah | evam sthānadṛștigaṇitāgatadṛsțyor aikyāt tukajyotirvidoktam eva dṛștigaṇitam yuktisaham ālocayāmaḥ | atha dṛkkhecarānayanam uktạ̣ tājikālaṃkāre |

\section{khețādhișthitabhodayāvadhidhiyā nakrādilaìkodayān}

samyojyāptam itah phalam khaśaśibhị so 'ṃśädidrkkhecarah |

yukto bhair navabhis tatheștakhacaram rekhāt svadeśodayān

ekikrtya punas tathaiva khacarah sādhyo 'missapūrvo budhaih \|

yat syād yogadale tayoh sa bhavati spașto 'tha drștigrahah

syus tadbhāgamitā lavā yadi tadā dṛștị sphuțā socyate |

jñeyam drgjanitam śubhāśubhaphalam pūrṇam tato dhīmatā

keșāmein matam ìdrśam dṛśi mayā khecāriṇām bhāṣitam ||

yādavaḥ |

1 drașțūna] scripsi; dṛștyūna B G p.c.; drașțana N; dṛsțūna G a.c. K T; drașț̣̣̂na M 3 tryañke] aṃke G a.c. 8 rakebhyah] khakebhyaḥ G p.c. T 11 sthānadṛști] dụștịị B N G || aikyāt tuka] aikyādikaṃ M 12 saham] sahitam K T M \| dṛkkhecarānayanam] dṛkkhecarānam K 13 bhodayāvadhi] bhogyāvadhi B N G a.c. 15 rekhāt] reșāt B G; meșāt K T M 16 punas] tatas N 17 yat] yah K T M || yogadale] yāgadalaṃ K M; yogadalaṃ T || bhavati] vabhati K T 18 lavā yadi] lavādi ye $\mathrm{N} \quad 19$ dhīmatā] dhīmatāṃ M

1-8 drașțrūna ... śāstrāt] TM 4O-41

3 tryanke] The reading of $\mathrm{G}$ is another instance of confusion of the characters $a$ and trya in northern-style Devanāgarī.

20 Smarasimha: sic, presumably for purely metrical reasons. For this variation on Samarasimhha's name, see Gansten 2019. The values produced by the method of calculation given here by Tuka agree with Balabhadra's own, except when the remainder is 8 signs (a trine); but both methods differ from the values given by Samarasiṃha and Nìlakantha with regard to the two sextiles, the two squares, and the dexter trine. Tuka's method includes an adjustment for the sextiles to agree with Samarasimha, but provides no such adjustment for the squares. 
When the aspecting [planet] subtracted from the aspected one equals ten or two signs, the degrees and so forth divided by two and subtracted from fifteen; when three [or] nine [signs, subtracted] from thirty; when eight [or] four signs, tripled then halved [and subtracted] from fortyfive; when measuring nil or six signs, doubled [and subtracted] from sixty, is [the value of] the aspect here. When [the distance measures] two or ten signs, [the degrees should be] multiplied by four and one, [respectively], divided by three, [and subtracted] from forty and ten according to the treatise of Smarasimha. ${ }^{20}$

Here, the calculation of aspects is described only for the stated places of aspect, beginning with the third and eleventh, and not for other places. Moreover, the aspects described commence at the beginning of the sign and cease at the end of the sign. Because of the unity that thus prevails between aspects by place and aspects derived by calculation, we regard the calculation of aspects described by Tuka Jyotirvid as [the most] proper. Next, the calculation of planets of aspect is described in the Täjikālaṃkära:

Adding together the right ascensions [in palas] beginning from Capricorn up to the end of the ascensions of the sign occupied by a planet, the resulting figure divided by ten is the planet of aspect in degrees and so on with nine signs added. Likewise, the wise should then find [the position of] the planet in degrees and so on by adding the planet sought to the [oblique] ascensions of its own place from the line [of the equator]. What is produced by half the sum of those two [figures] will then be the true planet of aspect. If the degrees [of the aspect] correspond to its degrees, then the aspect is called true. From that the wise should understand the full good and evil results arising from an aspect: this is the opinion of some on the aspects of the planets [as] related by me. ${ }^{21}$

Yādava [says in Tājikayogasudhānidhi 5.16]:

21 This procedure is clearly based on the concept of mixed ascensions discussed in section 4.4 below (see Chapter 4, note 37), although the present description appears even more corrupt. Rekha 'line' usually refers to the prime meridian, but must be understood here as the equator, as distance from the equator (terrestrial latitude) is what determines the ascensions 'of one's own place', i.e., oblique ascensions. 
evaṃ tayor antarabhāgakāś ca

dīptāịśatulyā yadi yogakārye|

yogottham iștam yadi vā hy aniștam

graho 'tra datte kila vakṣyamānam || iti |

atha dṛștịganite viśeṣāntaro miśroktah |

dṛśyasya draștrā rahitasya bhāgā gajendutaś ced adhikāh kharāmāt | sodhyāh punas te ravito viśodhyāh svadīptabhāgād athavā viśodhyāh $\|$ na ced viśudhyanti tadā na dṛk syād yathoktadṛksthānakalā vinighnāhn| divākarair dīptalavaih krameṇa bhaktāh sphuțā drșțikalā bhavanti || iti |

grahadṛșțiprayojanam āha vāmanah |

phalam dṛștipramānenena svayam yacchanti khecarāḥ | tat phalaṃ balamānena jñātvādeśyam śubhāśubham || iti |

atha dṛșțipradhānatvān maitrīcakrasya pūrvam dṛșțayo 'bhihitās tatrāvasaraprāptạ̣ maitrīcakram ucyate | tatra maitrīcakram caturvidham | ekaṃ dṛștivaśena mitrasamaśatrurūpam | dvitīyam dṛ̦țivaśenādhimitramitrasamaśatrvadhiśatrurūpam | tṛtīyaṃ dṛștivaśena mitraśatrurūpam | caturtham dṛștịm vinaiva niyatamitraśatrurūpam | tatra prathamam tridhāmaitryādisahitạ̣ maitrīcakram uktạ̣ romakatājike |

1 antarabhāgakāś] abhāgakāś K; arambhakāś T; aṃśakabhāgakāś M 3 vā hy anișțaṃ] vā svanișțhaṃ B N G a.c.; bāhyanișțham M 6 drașțrā] dṛștā B G; drașțā N K T 7 bhāgād] bhād G 8 sthāna] tena K T M 12 jñātvādeśyaṃ] jñātvādeśaṃ B N G 16 mitra ${ }^{1}$ om. B G K T M $\|$ tṛtīyam ... rūpam²] om. B N G a.c.

1-4 evam ... vakșyamāṇam] TYS 5.16 
And if the distance in degrees between the two is thus equal to [or less than] the orb of light as they form a configuration, the planet here gives [the result] described below as arising from the configuration, whether desirable or undesirable.

Then another special rule of calculating aspects is described by Miśra:

If the degrees [of longitude] of the aspected [planet] minus the aspecting one are more than eighteen, they should be subtracted from thirty, subtracted from twelve, or subtracted from their own orb of light. If they cannot be subtracted, then there is no aspect. ${ }^{22}$ The points as declared for the place of aspect, multiplied by twelve and divided by the respective orb of light, are the exact aspect [value] in points.

Vāmana describes the purpose of the aspects of the planets:

The planets themselves give results in proportion to their aspects. Understanding those results according to their measure of strength, one should predict the good and evil.

\subsection{Schemes of Friendship and Enmity}

Now, because the table of friendships is dependent on the aspects, the aspects have been set forth first; but now the proper time has come to describe the table of friendships. And the table of friendships is of four kinds. One takes the form of friends, neutrals and enemies on account of aspects. The second takes the form of great friends, friends, neutrals, enemies and great enemies on account of aspects. The third takes the form of friends and enemies on account of aspects. The fourth, without [considering] aspects, takes the form of constant friends and enemies. Of these, the first table of friendships, comprising a threefold [scheme of] friendship and so forth, is described in the Romakatäjika:

22 The instructions as given make little sense, as a figure of 18 or above can never be subtracted from 12, nor from the orb of light of any planet (the greatest of which is $15^{\circ}$ ), while the distance remaining in the aspect can never exceed 30 . 
mitram tritīyapañcamanavamaikādaśagato 'piyo yasya |

dhanaripumrtirișpheșu ca samo grahah syād iti jñeyam ||

śatrus tathaikaturye jāyāsthāne tathā daśame|

tājikahillājamatenaitādṛk kathitam asmābhị̣ || iti |

mitram samạ̣ śatruh

\begin{tabular}{lll}
\hline 9 & 2 & 1 \\
5 & 6 & 4 \\
3 & 8 & 7 \\
11 & 12 & 10 \\
\hline
\end{tabular}

dvitīyạ̣ viśeșabalopayuktaṃ pañcadhāmaitryādiyutaṃ maitrīcakram uk- 10 tạ̣ muktāvalyām |

yah pratyakșamamatvadrșțiphalado jñeyo 'dhimitrābhidho guptasnehadrśātha paśyati ca yo yam mitram asya smrtah | naivālokayatīha yah sa tu samo yo guptadaurjanyadrg draștā śatrur athādhiśatrur apiyaḥ pratyakșadaurjanyadṛk || iti |

adhimitrādicakram

$\begin{array}{lllll}\text { adhimitram } & 5 & 9 & & \\ \text { mitram } & 3 & 11 & & \\ \text { samah } & 2 & 6 & 8 & 12 \\ \text { śatruḥ } & 4 & 10 & & \\ \text { adhiśatruh } & 1 & 7 & & \end{array}$

1 yasya] jasya $\mathrm{K} \quad 10$ maitryādiyutam] om. K T 12 mamatva] samatva K T M $\|$ dṛștị] dṛștịh B N G 13 smṛtaḥ] smṛtạ̣ K T; smṛtam M 14 yaḥ] om. B N a.c. G 15 draṣṭā] dṛsțā B G; dṛṣtyā K T M 16 adhimitrādicakram] om. N G K T M

12-15 yah ... dṛk] TM 46

5 mitram] The following table is omitted by G N K T M, while B uses abbreviations. $\quad 16$ adhimitrādicakram] The following table is omitted by N K T M. 
A planet occupying the third, fifth, ninth or eleventh from another is a friend; in the second, sixth, eighth or twelfth it should be understood to be neutral; an enemy likewise in the first or fourth, and also the tenth: in this manner have we explained [the friendship scheme] according to the school of the Tājika Hillāja.

\begin{tabular}{lll}
\hline Friendly & Neutral & Inimical \\
\hline 9 & 2 & 1 \\
5 & 6 & 4 \\
3 & 8 & 7 \\
11 & 12 & 10 \\
\hline
\end{tabular}

The second table of friendships, employed for [ascertaining] particular strength and comprising a fivefold [scheme of] great friendship and so forth, is described in [Tājika]muktāvali [46]:

One who gives the result of an aspect of open friendship should be known by the name of great friend; one who aspects any [planet] with an aspect of secret friendship is called its friend; one who does not aspect at all is neutral; one aspecting with an aspect of secret enmity is an enemy; and a great enemy is one [who aspects] with an aspect of open enmity.

Table of great friends, etc.:

\begin{tabular}{ll} 
Great friends & 5,9 \\
Friends & 3,11 \\
Neutral & $2,6,8,12$ \\
Enemies & 4,10 \\
Great enemies & 1,7 \\
\hline
\end{tabular}


tṛtīyam mitraśatrurūpaṃ maitrīcakram uktaṃ tatraiva |

iștāniștekșakau khețau nekșakau ca śubhāśubhau|

yad vā mitraripū jñeyau svadrinmānānumānatah || iti |

caturthaṃ niyatamitraśatrurūpaṃ dvividhaṃ maitrīcakram uktạ̣ tājikasāre |

mitrāny āraśaśäñkaśakrasacivā bhaumārkadevārcitā

j̄̄̄ārkakṣaṇadādhipāh śanisitau candrārkabhūnandanāḥ|

saumyādityabhavau śaśāṅkajasitau mandajñaśukrā ime

sūryāt syū ripavas tu tājikamate śeșā budhaiś coditāḥ || iti |

mitraśatrucakram

\begin{tabular}{lll}
\hline & mitram & śatrụ̣ \\
\hline sūryaḥ & caṃ maṃ gu & bu rā śu śa \\
candrạ̣ & sū maṃ gu & bu rā śu śa \\
mañgalaḥ & sū caṃ gu & bu rā śu śa \\
budhaḥ & rā śu śa & sū caṃ mạ̣ gu \\
guruḥ & sū caṃ mam & bu rā śu śa \\
śukraḥ & rā bu śa & sū caṃ maṃ gu \\
śaniḥ & rā bu śu & sū caṃ mạ̣ gu
\end{tabular}

eșāṃ sarveșāṃ cakrānāạm yathāsampradāyaṃ vyavasthā drașțavyeti | maitrīcakraprayojanaṃ vakṣyamāṇapañcavargībale jñeyam | tad agre sarvaṃ 20 prakațîbhavișyati \||

1 śatrurūpaṃ] om. BNG a.c. $\quad 2$ |] śubhāśubham KTM 3 jñeyau] jeyau KM 6 mitrāṇy āra] mitrārāyāra M 9 ripavas] ripuvas B N a.c. G \| śeșā] jñeyā K T M || budhaiś] vuthaidiś B 10 mitraśatrucakram] om. B; mitrāmitraṃ sūryādīnām K T M

2-3 nișțekșakau ... mānatah] TM 42 6-9 mitrāṇy ... coditāḥ] TS 73

19 vyavasthā] With reference to this word, G adds in a different hand at the bottom of the page: ekasthānekavidhaprāptasyaikatraikavidhakathanam vyavasthā. 
The third table of friendships, taking the form of friends and enemies, is described there as well [Tājikamuktāvali 42]:

Planets of good or evil aspect, or not aspecting, should be known as benefic or malefic, or as friends and enemies, in accordance with the measure of their respective aspects. ${ }^{23}$

The fourth table of friendships, taking the twofold form of constant friends and enemies, is described in Tajikasāra [73]:

The friends [of the planets reckoned] from the sun are: [1] Mars, the moon and Jupiter; [2] Mars, the sun and Jupiter; [3] Jupiter, the sun and the moon; [4] Saturn and Venus; [5] the moon, the sun and Mars; [6] Mercury and Saturn; [7] Mercury and Venus; [8] Saturn, Mercury and Venus. According to the Tâjika school, the others are assigned as [their] enemies by the learned. ${ }^{24}$

Table of friends and enemies:

\begin{tabular}{lll}
\hline & Friends & Enemies \\
\hline Sun & Moon, Mars, Jupiter & Mercury, Rāhu, Venus, Saturn \\
Moon & Mars, Jupiter, sun & Mercury, Rāhu, Venus, Saturn \\
Mars & Sun, moon, Jupiter & Mercury, Rāhu, Venus, Saturn \\
Mercury & Rāhu, Venus, Saturn & Sun, moon, Mars, Jupiter \\
Jupiter & Sun, moon, Mars & Mercury, Rāhu, Venus, Saturn \\
Venus & Rāhu, Mercury, Saturn & Sun, moon, Mars, Jupiter \\
Saturn & Rāhu, Mercury, Venus & Sun, moon, Mars, Jupiter \\
\hline
\end{tabular}

The decision [on which] of all these tables [to use] should be made according to [one's own] tradition. The purpose of a table of friendships should be understood in [the context of] the five-dignity strength described below. This will all be made clear further on.

23 The verse is unclear about the status of planets that do not aspect. Perhaps they are meant to be grouped with those of evil aspect.

24 The sequence indicated by the numbers in square brackets refers to the planets in the order of rulers of the days of the week from the sun to Saturn, apparently with Rāhu added as the eighth. 
atha pañcavargībalam | tatprayojanam āha yādavasūrị̣ |

balaṃ viṃśopakajñānam pañcavargībalaṃ vinā |

na bhaved atha vaksyāmi pañcavargīprasādhanam || iti |

tājikālaṃkāre 'pi |

vīryājñāne varșanāthaprasiddhị

kartum śakyā naiva yasmāt samāsu|

jñātuṃ vīryam sūryatah khecarāṇām

tasmād vakșye pañcavargīvidhānam || iti |

pañcavargān āha samarasiṃhaḥ |

svagrham svoccaṃ haddā trairāśikam atha musallahaṃ ceti |

pañca grahādhikārā vinādhikāraṃ graho na balī || iti |

tadarthaṃ gṛheśān āha vāmanaḥ |

bhaumaśukrajñacandrārkabudhaśukrāramantrịaḥ|

saurị śanis tathā jīvo meṣādīnām adhīśvarāḥ || iti |

rāśisvāmicakram

\begin{tabular}{llllllll} 
svāmì & sū & caṃ & mam & bu & gu & śu & śa \\
\hline rāśị & 5 & 4 & 1 & 3 & 9 & 2 & 10 \\
& & & 8 & 6 & 12 & 7 & 11
\end{tabular}

1 āha] cāha K T M 5 vīryā-] vīryya- K T M \|| nātha] nāthạ̣ M || prasiddhiḥ] prasiddhah K T M 6 śakyā] śakyo M 9 vargān] vargīn B N G 12 gṛheśān] graheśān K 14 sauriḥ] scripsi; śauriḥ B N G K T M 15 rāśisvāmicakram] om. B N K T M

2-3 balam ... prasādhanam] TYS 4.14

15 rāśisvāmicakram] The following table is omitted by B N K T M. 


\subsection{The Five Dignities}

Next, the five-dignity strength. Its purpose is stated by Yādavasūri [in Tājikayogasudhānidhi 4.14]:

The strength [consisting in] knowledge of the twenty-point [scheme] cannot come to be without the five-dignity strength. Therefore I shall describe the arrangement of the five dignities.

And in the Täjikālaṃkāra [it is said]:

Because it is not possible to establish the ruler of the year without a knowledge of strength, I shall describe the method of the five dignities for knowing the strength of the planets [starting] from the sun in [different] years.

Samarasiṃha states the five dignities [in the Täjikaśāstra]:

Domicile, exaltation, haddā, triplicity and musallaha are the five dignities of the planets. Without dignity, a planet is not strong.

The domicile rulers [to be used] for that purpose are stated by Vāmana:

Mars, Venus, Mercury, the moon, the sun, Mercury, Venus, Mars, Jupiter, Saturn, Saturn and Jupiter are the rulers of [the signs] beginning with Aries.

Table of sign rulerships:

\begin{tabular}{llllllll}
\hline Ruler & Sun & Moon & Mars & Mercury & Jupiter & Venus & Saturn \\
\hline Sign & 5 & \multirow{2}{*}{4} & 1 & 3 & 9 & 2 & 10 \\
& & & 8 & 6 & 12 & 7 & 11 \\
\hline
\end{tabular}


atha grahāṇām uccanīcarāsīn tatparamoccān āha yādavaḥ |

meșo vrșo 'tha makaro mrgadṛk kulìro

minas tulä dinapapūrvakhagoccakāni $\mid$

āśāgnipiṇ̣̂atithivāyubhaviṃśatulyās

tuñgā lavāh svamadagās tu bhavanti nīcāḥ || iti |

\begin{tabular}{lll}
\hline grahāḥ & uccāni & nīcāni \\
\hline sūryaḥ & 010 & 610 \\
candraḥ & 13 & 73 \\
mañgalaḥ & 928 & 328 \\
budhaḥ & 515 & 1115 \\
guruḥ & 35 & 95 \\
śukrạ̣ & 1127 & 527 \\
śaniḥ & 620 & 0 20 \\
\hline
\end{tabular}

rāśișu haddeśāḥ saṃjñātantre |

meșe 'ñgatarkāṣtaśareșubhāgā jīvāsphujịjiñ̄araśanaiścarānām|

vrșe 'ștașaṇnāgaśarānalāmsśāḥ śukrajñajīvārkikujeśahaddāḥ \|

yugme șadañgeșunagāngabhāgāḥ saumyāsphujijjīvakujārkihaddāḥ|

karke 'dritarkāñganagābdhibhāgāḥ kujāsphujịjjñejyaśanaiścarānāām ||

siṃhe 'ñgabhūtādrirasāingabhāgā devejyaśukrārkibudhārahaddāḥ|

strìām nagāśābdhinagākșibhāgāḥ saumyośanoj̄̄vakujārkināthāḥ ||

tule rasāṣtāadrinagadvibhāgāḥ koṇajñajīvāsphujidārahaddāḥ|

3 dinapa] dinava M 4 āśāgni] aṃśāgni K T M $\quad 5$ mada] naga K T M 16 vṛṣe 'șțașaṇnāga] vṛșaștannnāga B $\quad 20$ nagākṣi] nāgāgākṣa K; nagākṣa T M 21 haddāḥ] nāthāḥ G p.c.

2-5 meșo ... nīcāḥ] TYS 4.16 15-190.5 meșe ... carāṇām] ST 1.33-38

6 grahāh] The following table is omitted by N. G separates figues for signs and degrees; K T M omits the top row. 
Next, the signs of exaltation and fall for the planets, [and] their [degrees of] highest exaltation, are stated by Yādava [in Tājikayogasudhānidhi 4.16]:

Aries, Taurus, Capricorn, Virgo, Cancer, Pisces and Libra are the exaltations of the planets beginning with the sun. Ten, three, twenty-eight, fifteen, five, twenty-seven and twenty, [respectively], are their highest degrees; [the signs] in the seventh from their respective [exaltations] are their [signs of] fall. ${ }^{25}$

\begin{tabular}{lll} 
Planet & Exaltation & Fall \\
\hline Sun & 0,10 & 6,10 \\
Moon & 1,3 & 7,3 \\
Mars & 9,28 & 3,28 \\
Mercury & 5,15 & 11,15 \\
Jupiter & 3,5 & 9,5 \\
Venus & 11,27 & 5,27 \\
Saturn & 6,20 & 0,20 \\
\hline
\end{tabular}

The rulers of the haddās within the signs [are listed] in Samjñãtantra [1.3338]:

In Aries, six, six, eight, five and five degrees belong to Jupiter, Venus, Mercury, Mars and Saturn, [respectively]; in Taurus, eight, six, eight, five and three degrees are the haddās ruled by Venus, Mercury, Jupiter, Saturn and Mars; in Gemini, six, six, five, seven and six degrees are the haddās of Mercury, Venus, Jupiter, Mars and Saturn; in Cancer, seven, six, six, seven and four degrees belong to Mars, Venus, Mercury, Jupiter and Saturn; in Leo, six, five, seven, six and six degrees are the haddās of Jupiter, Venus, Saturn, Mercury and Mars; in Virgo, seven, ten, four, seven and two degrees are ruled by Mercury, Venus, Jupiter, Mars and Saturn; in Libra, six, eight, seven, seven and two degrees are the had-

25 Again, the planets are counted in the standard Indian order of the days of the week. The highest exaltation of the sun at $10^{\circ}$ Aries is the classical Indian figure, probably due to a corruption in the early transmission; the Hellenistic and Perso-Arabic traditions have $19^{\circ}$ Aries. See Pingree 1978 II: $220 \mathrm{f}$. with the additional remarks in Gansten 2018: 171; cf. also Heilen 2015: 713-717, Brennan 2017: 242-248. 
kīte nagābdhyaștaśarāṅgabhāgā bhaumāsphujïjñejyaśanaiścarānām \|

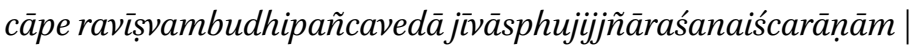
mrge nagādryaștayugaśrutīnām saumyejyaśukrārkikujeśahaddāh \| kumbhe nagāngādriśareșubhāgā jñaśukrajīvāraśanaiścarānām| mīne 'rkavedānalanandapakșāh sitejyasaumyāraśanaiścarānāām \|

haddācakram

\begin{tabular}{|c|c|c|c|c|c|}
\hline meșaḥ & bṛ 6 & śu 6 & bu 8 & mam 5 & śa 5 \\
\hline rșabhahạ & śu 8 & bu 6 & bṛ 8 & śa 5 & mam \\
\hline nithunah & bu 6 & śu 6 & br 5 & mam 7 & śa 6 \\
\hline rkatah & mam & śu 6 & bu 6 & br & śa 4 \\
\hline$n$ & bṛ 6 & śu 5 & śa 7 & $\mathrm{bu}$ & mam 6 \\
\hline anyā & bu 7 & śu 10 & bṛ 4 & mam 7 & śa 2 \\
\hline ulā & śa 6 & bu 8 & br 7 & śu ? & mam 2 \\
\hline ścil & mam & śu 4 & bu 8 & br 5 & śa 6 \\
\hline Iar & bṛ 12 & śu 5 & bu 4 & mam 5 & śa 4 \\
\hline akarah & bu 7 & br 7 & śu 8 & śa & mam 4 \\
\hline umbhah & bu 7 & śu 6 & bṛ 7 & mam 5 & śa 5 \\
\hline înạ & śu 12 & bṛ 4 & bu 3 & mam 9 & śa 2 \\
\hline
\end{tabular}

atha trairāśikeśā uktās tājikālaṃkāre |

meșe bhaumārkaśukrā budhavidhuśanaya h syur vrṣe yugmarāśau devejyakṣmājasūryāḥ sitabudhaśaśinaḥ karkațe sampradișțāh | siṃhe mandejyabhaumā ravisitaśaśijāh syur yuvatyām tulāāạm candrārkījyās tathālau kujaravikavayo jñendumandāśs ca cāpe \|

3 nagādry] nagāghry K T; nagāṃghry M \|| saumyejya] somejya M 4 śukra] śu K 6 haddācakram] om. B N K T M 19 trairāśikeśā] trairāśikeṇa G p.c.

6 haddācakram] In the following table, all witnesses abbreviate the names of the zodiacal signs and planets. $\mathrm{G}$ has $g u$ for $b r$ throughout, with no difference in meaning. $\mathrm{N}$ lists not the extension of each division but rather its termination degree. 
dās of Saturn, Mercury, Jupiter, Venus and Mars; in Scorpio, seven, four, eight, five and six degrees belong to Mars, Venus, Mercury, Jupiter and Saturn; in Sagittarius, twelve, five, four, five and four [degrees] belong to Jupiter, Venus, Mercury, Mars and Saturn; in Capricorn, seven, seven, eight, four and four [degrees] hold the haddās of Mercury, Jupiter, Venus, Saturn and Mars; in Aquarius, seven, six, seven, five and five degrees belong to Mercury, Venus, Jupiter, Mars and Saturn; in Pisces, twelve, four, three, nine and two [degrees] belong to Venus, Jupiter, Mercury, Mars and Saturn. ${ }^{26}$

Table of haddās:

\begin{tabular}{llllll}
\hline Aries & Jupiter 6 & Venus 6 & Mercury 8 & Mars 5 & Saturn 5 \\
Taurus & Venus 8 & Mercury 6 & Jupiter 8 & Saturn 5 & Mars 3 \\
Gemini & Mercury 6 & Venus 6 & Jupiter 5 & Mars 7 & Saturn 6 \\
Cancer & Mars 7 & Venus 6 & Mercury 6 & Jupiter 7 & Saturn 4 \\
Leo & Jupiter 6 & Venus 5 & Saturn 7 & Mercury 6 & Mars 6 \\
Virgo & Mercury 7 & Venus 10 & Jupiter 4 & Mars 7 & Saturn 2 \\
Libra & Saturn 6 & Mercury 8 & Jupiter 7 & Venus 7 & Mars 2 \\
Scorpio & Mars 7 & Venus 4 & Mercury 8 & Jupiter 5 & Saturn 6 \\
Sagittarius & Jupiter 12 & Venus 5 & Mercury 4 & Mars 5 & Saturn 4 \\
Capricorn & Mercury 7 & Jupiter 7 & Venus 8 & Saturn 4 & Mars 4 \\
Aquarius & Mercury 7 & Venus 6 & Jupiter 7 & Mars 5 & Saturn 5 \\
Pisces & Venus 12 & Jupiter 4 & Mercury 3 & Mars 9 & Saturn 2 \\
\hline
\end{tabular}

Next, the triplicity rulers are described in the Täjikälaṃkāra:

In Aries, Mars, the sun and Venus; in Taurus, they are Mercury, the moon and Saturn; in the sign of Gemini, Jupiter, Mars and the sun; in Cancer, Venus, Mercury and the moon are assigned; in Leo, Saturn, Jupiter and Mars; in Virgo, they are the sun, Venus and Mercury; in Libra, the moon, Saturn and Jupiter; then in Scorpio, Mars, the sun

26 With two exceptions, this list corresponds to the standard version of the so-called Egyptian terms; cf. Ptol. Tetr. I 21. The exceptions are the terms of Venus and Jupiter in Gemini, the order of which has been reversed, and likewise the terms of Mars and Saturn in Sagittarius. In neither case could the order be changed without intrusive emendation to the received text of Nīlakanțha's work. 
makare gurubhaumapadminissáh̆ sitaviccandramaso ghațe niruktāh | śanivākpatibhūmijās tu mine kathitāḥ sadganakair dṛkānanāthāḥ || iti |

dreșkāṇacakram

\begin{tabular}{|c|c|c|c|}
\hline & aṃśāḥ 10 & aṃśāḥ 20 & aṃśāḥ 30 \\
\hline 1 & maṅgalaḥ & ravih & śukrah \\
\hline 2 & budhah & candrah & śaniḥ \\
\hline 3 & guruh & man்galah & raviḥ \\
\hline 4 & śukrah & budhah & candrah \\
\hline 5 & śanih & guruh & mañgalah \\
\hline 6 & ravih & śukrah & budhah \\
\hline 7 & candrah & śaniḥ & guruh \\
\hline 8 & mañgalaḥ & ravih & śukrah \\
\hline 9 & budhah & candrah & śaniḥ \\
\hline 10 & guruh & mañgalah & ravih \\
\hline 11 & śukrah & budhah & candrah \\
\hline 12 & śaniḥ & guruh & man்galaḥ \\
\hline
\end{tabular}

trairāśikeśvarā lāghavenoktāḥ saṃjñātantre |

$\bar{a}$ dyāḥ kujādyā ravito 'pi madhyamāḥ sitāt tṛtīyāḥ kriyato dṛkānaapāḥ | iti |

atilāghavena trairāśikeśvarā uktā haribhaț̣adaivajñaiḥ |

1 guru] kuru G 3 dreșkāṇacakram] om. B N K T M 5 ra] sū B

18 ādyāh ... dṛkāṇapāḥ] ST 1.30

3 dreșkānacakram] In the following table, N K T M have $b r$ for $g u$ throughout; G K T M have $s \bar{u}$ for $r a$ throughout. $\mathrm{G}$ adds a row with the headings $r \bar{a}^{\circ}$; prathamadre $e^{\circ}$; $v i^{\circ} d r e^{\circ} ; t r^{\circ} d r e^{\circ}$ and designates the signs of the zodiac with abbreviated forms of their names instead of numbers. 
and Venus; Mercury, the moon and Saturn in Sagittarius; in Capricorn, Jupiter, Mars and the sun; in Aquarius they are said to be Venus, Mercury and the moon; and in Pisces, Saturn, Jupiter and Mars are designated by true astrologers as rulers of the decans. ${ }^{27}$

Table of decans:

\begin{tabular}{llll}
\hline & 1o degrees & 2o degrees & 3o degrees \\
\hline Aries & Mars & Sun & Venus \\
Taurus & Mercury & Moon & Saturn \\
Gemini & Jupiter & Mars & Sun \\
Cancer & Venus & Mercury & Moon \\
Leo & Saturn & Jupiter & Mars \\
Virgo & Sun & Venus & Mercury \\
Libra & Moon & Saturn & Jupiter \\
Scorpio & Mars & Sun & Venus \\
Sagittarius & Mercury & Moon & Saturn \\
Capricorn & Jupiter & Mars & Sun \\
Aquarius & Venus & Mercury & Moon \\
Pisces & Saturn & Jupiter & Mars \\
& & & \\
\hline
\end{tabular}

The triplicity rulers are concisely described in Samjñātantra [1.30]:

The first ones beginning with Mars, the middle ones [counted] from the sun, and the third ones from Venus: [these] are the rulers of the decans [counted] from Aries. ${ }^{28}$

Haribhaț̣a Daivajña describes the triplicity rulers very concisely: ${ }^{29}$

27 For the confusion introduced here concerning triplicities, decans and ninth-parts, see the Introduction and Gansten 2018.

28 The meaning of this terse formula is that the rulers of the first decans $\left(0^{\circ}-10^{\circ}\right)$ of the twelve zodiacal signs, beginning with Aries, follow in the Indian planetary order (based on the days of the week) counted from Mars. The rulers of the middle decans $\left(10^{\circ}-20^{\circ}\right)$ of the same signs follow in the same order counted from the sun, and the rulers of the last decans $\left(20^{\circ}-30^{\circ}\right)$, counted from Venus.

29 I have not been able to locate this stanza in available independent witnesses of the Tājikasāra. 
dviśūnyapañcayugrāśeh saptataște dṛkāṇapāh |

atra rāśir vartamāno jñeyah | vartamānarāśị prathamadreṣkāṇe dviyuto dvitīyadreșkāne śūnyayutas tṛtīyadreșkāṇe pañcayuk kartavyaḥ | saptatașțe sūryād dreșkāṇasvāmī bhavatīty arthah \|

musallahā uktās tājikaratnamālāyām |

muśallahāh syuh kriyanakrajūkakulīrapūrvāḥ kriyapūrvakānāam | iti |

etat spaștam āha yādavasūriḥ |

ajadhanurharayo 'jamukhāh smṛtās tv alikulīrajhașāś ca kulīratah | dhațamukhā ghațayugmadhațā matā mrgavrṣainadṛśo makarādayaḥ || iti | atra tājikabhūṣaṇatājikālaṃkārādau musallaheśā anyathaivoktāḥ |

ravījyamandāḥ sitacandrabhaumāḥ śanijñajīvāh kavibhaumacandrāḥ| muśallaheśā ajato mrgendrād dhanurdharād ahni niśi dvayor vā || iti |

naitad ramyam | yatạ̣ samarasiṃhenaite varṣeśanirṇayārthaṃ trairāśikeśvarā uktā na tu musallaheśāḥ |

meșādicatustrairāśikeśvarā ravisitārkibhrgavo 'hni| guruśaśibudhabhaumā niśi śanikujagurvindavah satatam || iti |

1 rāśeh ] rāśis K T M 2 rāśir vartamāno] vartamāno rāśir KT M $\quad 2-4$ vartamāna ... arthah] om. B N G 6 muśallahāḥ syuḥ] muśallahākhyāḥ B G p.c.; muśallakhyāḥ N G a.c. \| jūka] yūk B; yuk N G 7 spaștam] spașțaṇadṛśom K; spaștena dṛśa M 8 mukhāḥ] mukhāt K T M \| jhașāśs rșāáś G a.c.; hayāś G p.c. 9 ghața] dhața G M \| dhațā] ghațā G T M \| vṛsai-

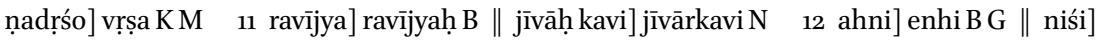
niśir B G || dvayor vā || iti] dvayoś ceti N 13-14 trairāśikeśvarā uktā] trairāśikesva urāktā N 15 'hni] hi M

8-9 aja ... -ādayaḥ] TYS 4.6 11-12 ravījya ... vā] TBh 1.31 $\quad$ 15-16 meșādi ... satatam] Cf. KP 1.21

7 spaștam] $\mathrm{K}$ and $\mathrm{M}$ reproduce the same error, transposing most of the phrase $v$ rșainadríso from the following stanza here, possibly as the result of a common source witness having been damaged and imperfectly restored. 9 mrga ... -ādayah] M prefaces its metrically deficient version with a question mark. 
The rulers of the decans [are found] from the sign with two, nil or five added, when reduced by multiples of seven.

That is, here [the number of] the current sign should be known. The current sign should be added to two in the first decan, added to nil in the second decan, and added to five in the third decan. When reduced by multiples of seven, [the resulting number counted] from the sun becomes the ruler of the decan. ${ }^{30}$

The musallahas are described in the Täjikaratnamālā:

The musallahas of the [signs] beginning with Aries begin with Aries, Capricorn, Libra and Cancer, [repeating three times].

The same is clearly stated by Yādavasūri [in Täjikayogasudhānidhi 4.6]:

Aries, Sagittarius and Leo are said to begin with Aries; Scorpio, Cancer and Pisces [are counted] from Cancer; Aquarius, Gemini and Libra are considered to begin with Libra; Capricorn, Taurus and Virgo begin with Capricorn.

These rulers of the musallahas are described quite differently in the Täjikabhūṣaṇa, the Tãjikālaṃkāra and so on, [as here in Tājikabhūṣaṇa 1.31]:

The sun, Jupiter and Saturn; Venus, the moon and Mars; Saturn, Mercury and Jupiter; Venus, Mars and the moon: [these are] the rulers of the musallahas from Aries, from Leo, [and] from Sagittarius, by day, by night, and at both [times].

[But] this is not agreeable, for those are the triplicity rulers described by Samarasiṃha [in the Tãjikaśāstra] ${ }^{31}$ for determining the ruler of the year, not the rulers of the musallahas:

The triplicity rulers of the four [signs] beginning with Aries are the sun, Venus, Saturn and Venus by day; Jupiter, the moon, Mercury and Mars by night; and, Saturn, Mars, Jupiter and the moon at all times.

30 The order of the planets is once more that of the days of the week.

31 Although the stanza quoted here also occurs in Samarasiṃha's Karmaprakāśa, known to Balabhadra as the Manusyajätaka, it is quoted again below (5.7) as part of a longer passage not found in the Karmaprakāśa. 
ete dinarātrivibhāgoktās trairāśikeśvarā varṣeśārtham evety uktạ̣ saṃjñātantre $\|$

varșeśārthaṃ dinaniśâvibhāgoktās trirāśipāḥ | iti |

tasmād atra pūrvoktā navāṃśeśā eva musallaheśāh | uktạ̣ ca sudhānidhau |

muśallahaṃ navāṃśaṃ ca kathitam tājike mate | iti |

tājikatilake 'pi |

muśallaheśās tu navāmśanāthāḥ proktāḥ sadā khindakaromakādyaiḥ| iti |

tājikamuktāvalyām api |

musallaheśān navamāṃśapān ye jagur mate khindakaśāstravījñạ̣ | iti |

atha pañcavargīphalam uktaṃ yādavena |

svakīyagehādibhavā śubhā syāt pāpārijātā viparītabhāvā|

mitrādijā madhyaphaleșuvargīviśeșavīryānayanam bruve 'ham ||

3 niśā] niśor K T M \| vibhāgoktās] bhoktās $\mathrm{G} \quad 8$ muśallaheśās tu] muśallaheśāś ca K T M 1o mate] na te K T M

3 varșeśārtham ... trirāśipāḥ] ST 1.61 6 muśallahaṃ ... mate] TYS $4.25 \quad 10$ musallaheśān ... vijñāḥ] TMṬ 1.15 12-13 svakīya ... 'ham] TYS 4.26

10 mate] Although the correct reading of the original line is undoubtedly na te (supported by MS TMṬ1), this would contradict Balabhadra's argument, and we must therefore assume that the mate of the three earliest witnesses reflects the reading followed by Balabhadra. 
That these triplicity rulers are described according to division by day and night only for the sake of [ascertaining] the ruler of the year is declared in Samjñātantra [1.61]:

The triplicity rulers are described according to division by day and night for the sake of [ascertaining] the ruler of the year.

Therefore, the musallaha rulers are only the rulers of the ninth-parts previously described here. And [Tājikayoga] sudhānidhi [4.25] says:

And the ninth-part is called musallaha in the Täjika school.

And in the Täjikatilaka:

The rulers of the ninth-parts are always called the rulers of the musallahas by Khindika, Romaka and so on.

And in Tājikamuktāvali[țippaṇi 1.15]:

[Those] who say that the rulers of the ninth-parts are rulers of the musallahas are versed in the doctrine of Khindika according to [his] school. ${ }^{32}$

Next, Yādava describes the results of the five dignities [in Tajjikayogasudhānidhi 4.26]:

The fivefold position arising from one's own domicile and so on is good; that produced by malefics and enemies is evil; that produced by friends and so on gives middling results. I shall describe the calculation of exact strength.

32 This somewhat awkward translation reflects the reading of the earlier text witnesses of the Hāyanaratna (B N G), presumably that followed by Balabhadra. Other text witnesses, as well as independent MSs of the Tajjikamuktāvalițippañi, support the more plausible and grammatical reading: 'Those who say that the rulers of the ninth-parts are rulers of the musallahas are not versed in the doctrine of Khindika.' This, however, contradicts Balabhadra's argument as well as the preceding quotation. 
atha pūrvaṃ grahabalajñānārthaṃ sthānāny uktāni | idānīṃ kasmin sthāne kiyad balam ity uktam grahajñābharaṇe |

triṃśat svabhe viṃśatir uccage syāt tithị svahadde daśakaṃ dṛkāne | navāṃśake pañca bhavanty aśítir evaṃ yugāptāś ca viśopakāh syụ̣ || iti |

atha mitrasamaśatrurūpe maitrīcakre balavibhāga uktaḥ saṃjñātantre |

svasvādhikāroktabalam suhrdbhe

pādonam ardham samabhe 'ribhe 'nighrị. |

evam samānīya balam tadaikye

vedoddhrte hīnabalaḥ śaronah || iti |

uccabalānayanam uktaṃ vāmanena |

nīconito grahah șaḍhādhiko maṇdalaśodhitạ |

śeșasyāmeśā nandabhaktā balam uccasya jāyate || iti |

athātra māmakaṃ padyam |

nīcagrahāntaraṃ kāryaṃ șaḍbhād alpaṃ yathā bhavet |

tadaṃsaannkalavaḥ svoccabalaṃ syāt tājike sphuṭam || iti |

nīce grahạ śodhyo nīcaṃ vā grahe śodhyaṃ śodhite sati yat șaḍbhād alpaṃ bhavet | tasyāṃśā navabhaktā uccabalaṃ syād iti ||

athādhimitramitrasamaśatrvadhiśatrurūpe maitrīcakre balavibhāga uktas tājikatilake |

1 pūrvaṃ] sarvam $B \mathrm{~N}$; sarvah $\mathrm{G}$ a.c. \| bala] la T 4 aśítir] aśíti B N G 5 rūpe] rūpa B N G 11 șạ̣bhādhiko] șaḍbhād adhiko G p.c. $\quad 13-17$ athātra ... iti] om. B N G a.c. 15 tadaṃśānika] tadāṃśāṃka K T M 16 yat] yathā K T M 17 bhavet] bhavati tathā kāryaṃ K T; bhavati tathā kāryam M 18 mitramitra] mitrāmitra N

6-9 svasvādhi ... śaronaḥ] ST 1.40 
Thus the places [of the five dignities] for knowing the strength of a planet have been described first. Now, the Grahajñäbharaña describes how much strength [a planet gains] in each place:

There will be thirty [points] in its domicile, twenty when it is exaltated, fifteen in its own haddā, ten in its decan, five in its ninth-part. [The points] thus are eighty; divided by four, they become the twenty-point strength.

Next, the division of strength in the table of friendships taking the form of friends, neutrals and enemies is described in Samjñātantra [1.40]:

The strength assigned to each dignity of [the planet] itself is less by a quarter in the sign of a friend, half in the sign of a neutral, a quarter in the sign of an enemy. Calculating the strength thus and dividing the sum by four, [a planet] with less than five [points is considered] weak.

The calculation of exaltation strength is described by Vāmana:

The [longitude of the] planet is subtracted from its [degree of] fall [and the result] subtracted from the circle [if it is] greater than six signs. The degrees of the remainder, divided by nine, becomes its strength of exaltation.

Here is a verse of my own on this matter:

The distance between the [degree of] fall and the planet should be measured so that it is less that six signs: a ninth of those degrees is the exact exaltation strength in the Täjika [school].

The planet should be subtracted from the [degree of] fall, or the [degree of] fall subtracted from the planet, so that less than six signs remain after subtraction. The degrees of that [distance], divided by nine, will be the exaltation strength.

Next, the division of strength in the table of friendships taking the form of great friends, friends, neutrals, enemies and great enemies is described in the Tajjikatilaka: 
uktāh kalāh svarkșagate grahendre pratyekavargaṃ tv adhimitragehe | svānghryamśahīnā hitagehasaṃsthe svārdhonitāh svānghrilavatrayonāḥ || samarkșage śatrugṛhopayāte nijāsțtamāṃśapramitam balaṃ syāt | adhidvișadbhopagate svakīye nrpāmśaliptā iti vargavīryam | yathāgatam tungabalam tu tena samanvitaṃ vargabalaṃ balaṃ syāt || iti |

mitraśatrurūpe maitrīcakre balam uktam paddhatau |

nijamitrāribhe trimśat tithyạ̣ sārdhādrayo balam | hadde tattaddalam tryaṃśo dreṣkāṇe 'ṃśe rasāṃśakaḥ || iti | aṃśe navāṃśe | etat spașțam uktaṃ tājikasāre | triṃśāmśa nijabhe svamitrabhavane ghasrāṃśakāḥ śatrubhe sārdhāh saptalavāh svakhāgnilavake bhāgās tu pañcendavaḥ| trị̣śāmśe nijamitraje nagalavāh sārdhāh krtāh śatrubhe pādonāh svagunāmenśake daśalavā vāṇāṃśakā mitrage \| dreșkāne sadalā yamās tv arigate nandāmśake sve śarā nandāṃse nijamitrage yamalavāh sārdhās tv arau taddalam | iti |

tadaikyaturyabhāgakapramāṇikā balonmitiḥ| daśādhike bale balī śarālpake 'lpavīryakah || iti |

1 vargam] varge N G a.c. K T M 2 lava] taca B G a.c.; tatra N 3 samarkṣage] samerkṣage $\mathrm{N} \quad 4$ gate] gatạ̣ B N G 7 mitrāri] mitrādi G p.c. 8 dalaṃ] dale B N G \| tryamśo] tryamśe K T M || 'ṃśe] ṃśa G 11 svakhāgni] khakhāgni G 12 mitraje] mitrabhe G p.c. K T M 13 daśa] dala K T M $\|$ mitrage] mitrabhe K T 14 tv arigate] varigate B N G a.c. $\quad 15$ arau] araus B N G 16 bhāgaka] bhāga K T M \| balonmitiḥ] balonmitaḥ K; balonmito M 17 bale] balo K T M

7-8 nija ... rasāṃśakah] PBh 30 10-15 triṃśāṃśā ... taddalam] TS 74-75 $\quad$ 16-17 tadaikya ... vīryakah] PBh 31 
The points assigned when a planet occupies its own place in each dignity is less by one quarter in the place of a great friend, less by half when occupying the place of a friend, less by three quarters when occupying a neutral place; it measures one eighth when occupying the domicile of an enemy, and one sixteenth when occupying the place of a great enemy: this is the strength by dignity. The strength by dignity added to the exaltation strength as [previously] derived is thus the [total] strength.

The strength in the table of friendships taking the form of friends and enemies is described in Paddhati [bhụșana 3o]:

In [a planet's] domicile, a friend's or an enemy's sign, [its] strength is thirty, fifteen and seven and a half, [respectively]. In [their respective] hadd $\bar{a}$, [the strength is] half of each; a third in the decan; and a sixth in the [ninth]-part.

'In the part' [means] in the ninth-part. This is described clearly in Täjikasāra [74-75]:

Thirty points in [the planet's] own domicile, fifteen points in the house of its own friend, seven and a half points in an enemy's sign; fifteen points in its own thirtieth-part, seven and a half points in the thirtiethpart of its own friend, four less by a quarter in the place of an enemy; ten points in its own third, five in that of a friend, but two and a half in the decan of an enemy; five in its own ninth-part, two and a half points in a ninth-part of one's own friend, but half of that in [the ninth-part of] an enemy. ${ }^{33}$

[Continuing from Paddhatibhūṣaṇa 31:]

The measure of strength comprises one fourth of the sum of these. ${ }^{34}$ When the strength exceeds ten, [the planet is] strong; when it is less than five, [the planet is] weak.

The Graeco-Arabic terms (Sanskritized as haddā) are here designated by the word trimśāmśa 'thirtieth-part', otherwise used for the pre-Islamic Indian version of the terms. As both types of terms are actually divisions of a sign into five unequal parts, the designation 'thirtieth-part' probably reflects the commonly used Greek synonym $\mu \circ \hat{i}$ al 'degrees', a degree being a thirtieth of a sign.

A play on words: pramānikā 'comprising' is also the name of the metre used. 


\begin{tabular}{lllll}
\hline & sva & mitra & sama & śatru \\
\hline gṛhabalam & 30 & 2230 & 150 & 730 \\
haddābalam & 15 & 1115 & 730 & 345 \\
dreșkāṇabalam & 10 & 730 & 50 & 230 \\
musallahabalam & 5 & 345 & 230 & 115 \\
\hline
\end{tabular}

pañcadhāmaitrīcakre balacakram idam

\begin{tabular}{lllll}
\hline & gṛham & haddā & dreṣkāṇạ & navāmśạ \\
\hline sva & 30 & 15 & 10 & 5 \\
adhimitra & 2230 & 1115 & 730 & 345 \\
mitra & 15 & 730 & 5 & 230 \\
sama & 730 & 345 & 230 & 115 \\
śatru & 345 & 152 & 115 & 037 \\
adhiśatru & 145 & 056 & 037 & 018 \\
\hline
\end{tabular}

śatrumitrarūpamaitrīcakrabalạ̣ ca

\begin{tabular}{llll}
\hline & svasya & mitrasya & śatrọ \\
\hline gṛham & 30 & 15 & 730 \\
dreșkāṇah & 15 & 730 & 345 \\
haddā & 10 & 5 & 230 \\
navāmṣsạ̣ & 5 & 230 & 115 \\
\hline
\end{tabular}

6 pañcadhāmaitrīcakre] pañcadhāmaitrīcakra G M; pañcadharmitrīcakra K T || idam] om. GKTM 9 2230] 22 31 KTM \| 11 15] 1215KTM \| 730] 73 KTM 11 345] 745 Ga.c. \| 2 30] 210 B Ga.c. 12345 ] o 15 KT M \| 152] o 56 KT M \| 115] o 37 KT M \| ० 37] o 18 KT M 14 śatrumitra] mitraśatru K T M || rūpa] rūpe B G \| cakrabalaṃ] om. K T M \| ca] om. G K T M 15 mitrasya] mitraṃ B; mitra T M 16 g̣̣ha] 18 K T M 17345$] 340$ T; 347 M

1 sva] The following table is omitted by N. The remaining text witnesses abbreviate some or all words. G adds in the top row: grhā. 6 pañcadhāmaitrīcakre] The following table is omitted by N. The remaining text witnesses abbreviate all words. K T M omit the row labelled adhiśatru. 14 śatrumitra] The following table is omitted by N. The remaining text witnesses abbreviate some or all words. 


\section{Own Friendly Neutral Inimical}

\begin{tabular}{lllll}
\hline Domicile strength & 30 & $22 ; 30$ & 15 & $7 ; 30$ \\
Haddā strength & 15 & $11 ; 15$ & $7 ; 30$ & $3 ; 45$ \\
Decan strength & 10 & $7 ; 30$ & 5 & $2 ; 30$ \\
Musallaha strength & 5 & $3 ; 45$ & $2 ; 30$ & $1 ; 15$ \\
\hline
\end{tabular}

This is a table of strengths in the fivefold friendship scheme:

\begin{tabular}{lllll}
\hline & Domicile & Hadda & Decan & Ninth-part \\
\hline Own & 30 & 15 & 10 & 5 \\
Great friend & $22 ; 30$ & $11 ; 15$ & $7 ; 30$ & $3 ; 45$ \\
Friend & 15 & $7 ; 30$ & 5 & $2 ; 30$ \\
Neutral & $7 ; 30$ & $3 ; 45$ & $2 ; 30$ & $1 ; 15$ \\
Enemy & $3 ; 45$ & $1 ; 52$ & $1 ; 15$ & $0 ; 37$ \\
Great enemy & $1 ; 45$ & $0 ; 56$ & $0 ; 37$ & $0 ; 18$ \\
\hline
\end{tabular}

And tabular strengths in a friendship [scheme] in the form of friends and enemies:

\begin{tabular}{llll}
\hline & Own & Friend's & Enemy's \\
\hline Domicile & 30 & 15 & $7 ; 30$ \\
Decan & 15 & $7 ; 30$ & $3 ; 45$ \\
Hadd $\bar{a}$ & 10 & 5 & $2 ; 30$ \\
Ninth-part & 5 & $2 ; 30$ & $1 ; 15$ \\
\hline
\end{tabular}


atra vāmanena lagnasyāpi pañcavargī kāryety uktam |

svoccaṃ navāṃśakaṃ haddā gṛam dreșkāṇa eva ca | salagnakhecarāṇām tu prokteyam pañcavargikā || iti |

atha varșeśadaśādhīśabalādinirṇayārtham vimisśopakavibhāgena nașțabalādilakṣaṇam uktaṃ tājikasāre |

vānair nașțabalo graho daśamitair madhyo viśopais tatạ̣ śreștho ghasramitaih sukhārthajanakah proktaḥ khadasrair bhavet | iti |

nanu vimśativiṃśopakātmakaṃ balaṃ kasyāpi grahasya nāyāti | tathā hi meșasthasūryasya uccabalādi yady api samāyāti tathāpi svag̣̣hatvābhāvān mitrasamaśatrugṛhādibhedakṛtabalatāratamyenāvaśyam nyūnatā sārdhadvayaviṃśopakamitā bhavaty eva | evaṃ sati sārdhāḥ saptadaśaviṃśopakā balam | siṃhasthasūryasya svag̣̣habalaṃ yady api samāyāti tathāpy uccarāśer abhāvād uccabalasya nyūnatāyāṃ ṣoḍaśaviṃśopakā balaṃ syān na tu viṃśativimiśopakātmakam ||

atha budhasya kanyāyāṃ pañcadaśāṃśe svag̣̣habalaṃ svoccabalaṃ ca pūrṇaṃ yady api samāyāti tathāpi haddādreșkāṇanavāṃśabalāni pūrṇāni na sambhavanti | yata ādimāḥ șaḍaṃśạ̣̄ kanyāyāṃ budhahaddā | antimas tribhāgo budhadreșkāṇah | antimam aṃśatrayaṃ viṃśatikalādhikaṃ budhanavāṃśạ̣ | yadi kanyāntimanavāṃśo g̣̣hyate tadā svag̣̣hadreṣkāṇasvanavāmśabalāni sampūrṇāny āyānti paraṃ tv ekaṃ saṃdhitsato 'param pracyavate iti nyāyād uccabalaṃ kiṃcid ūnaṃ haddādibalam api mitrādigehasattvān nyūnam | atạ̣ paramaṃ balaṃ yathā kathaṃcid așṭādaśavimśso-

3 salagna] salama K; sahamaṃ M || prokteyaṃ] proktoyaṃ KT 4 viṃśopaka] viṃśopakāM 6 vāṇair] vānaālpair K T; bāṇālpair M $\quad 7$ sukhārtha] sukhāthe $\mathrm{K} \quad 9$ svagṛhatvābhāvān] svagṛhatvān K T M 11 viṃśopakamitā ... eva] viṃśā $\mathrm{N}$ a.c.; viṃśopakānyūnabalā $\mathrm{N}$ p.c. || bhavaty] bhavety B G 15 svoccabalaṃ] om. B N G a.c. 17 ādimāḥ] ādibhāt B N; ādimāt G 18 viṃśatikalādhikaṃ] om. B N G 19 gṛha] scripsi; gṛhe B N G K T M 20 sampūrṇāny āyānti] sampuūrnādy ayāṃti B G; saṃpūrṇā"yāṃti N a.c. || saṃdhitsato] sandhivatsato K T M 21 pracyavate] pratyavata B N a.c. G; pravavata N p.c. \| balaṃ] calaṃ N; bale $\mathrm{T}$

6-7 vānair ... bhavet] TS 76 
Regarding this, Vāmana says that the five dignities should be applied to the ascendant as well:

Exaltation, ninth-part, haddā, domicile and decan: these are declared as the five dignities for the planets and the ascendant.

Now, for the sake of judging the strength of the ruler of the year, the ruler of the period and so on, the definitions of a powerless [planet] and so on by divisions of the twenty-point strength is stated in Täjikasāra [76]:

With [up to] five [out of] twenty points, a planet is declared to be powerless; with up to ten, middling; with up to fifteen, excellent; and with twenty, producing happiness and wealth.

Objection: no planet can attain a strength of twenty in the twenty-point scheme, [which may be proved] as follows: although the sun posited in Aries attains the strength of exaltation and so on, a deficiency amounting to two and a half points still necessarily results according to the proportions of strength based on the distinction between friendly, neutral and enemy signs and so on, because [the sun] is absent from its domicile. This being so, its strength is seventeen and a half points. [Likewise], although the sun posited in Leo attains the strength of domicile, still, by the deficiency in exaltation strength due to [the sun] being absent from its sign of exaltation, [its] strength will be sixteen points, not twenty points.

Moreover, although Mercury in the fifteenth degree of Virgo attains both full domicile strength and exaltation strength, yet the full strengths of $h a d d \bar{a}$, decan and ninth-part are not possible [to attain], because the haddā of Mercury is the first six degrees of Virgo; the decan of Mercury is the last third [of Virgo]; and the ninth-part of Mercury is the last three degrees and twenty minutes [of Virgo]. ${ }^{35}$ If we take the last ninth-part of Virgo, then [Mercury] attains full strength of domicile, decan and own ninth-part; but according to the adage 'Seeking one thing, one loses another', the exaltation strength is somewhat reduced, and the strength of hadd $\bar{a}$ and so on is likewise diminished, as [Mercury] will occupy the place of a friend and so on. ${ }^{36}$ Therefore,

35 All text witnesses agree on the reading 'six degrees', although it was established above (in agreement with most Greek and Arabic versions) that the terms of Mercury extend over the first $7^{\circ}$ of Virgo. There are actually two navāmśas or ninth-parts of Mercury in Virgo: $13^{\circ} 20^{\prime}-16^{\circ} 40^{\prime}$ and $26^{\circ} 40^{\prime}-30^{\circ}$ oo'.

36 Mercury would then be in the terms of Saturn rather than in its own terms. 
pakātmakaṃ syān na viṃśativimśśopakātmakam balam | anyeșāṃ tu svagṛhoccayor bhedād viṃśativimiśopakanyūnam eva balaṃ syāt ||

atra kecit pañcavargīdvādaśavargīharșasthānabalānām aikyạ̣ tribhaktaṃ yadi viṃśativiṃśopakamitaṃ syāt tadā pūrṇabalo graho jñeyaḥ | uktạ̣ ca yādavena |

\section{śrīsūryavargišaravargikāmutsthānotthavìryaikyam athāgnibhaktam |} ced viṃśatị pūrṇabalo grahạ̣ syād balānumānena ca madhyamādị̣ || iti |

alam atiprasangena | atha daśāphalajñānārthaṃ pañcaviṃśopakanyūnabalo naștabalaḥ pañcavimissopakātmakabalah svalpabalaḥ pañcādhikabalo madhyabalaḥ daśādhikabalạ̣ pūrṇabalaḥ | varșeśaphalajñānārthaṃ tu șaḍviṃśopakātmakabalo hīnabalah șaḍvimśopakādhikabalo madhyabalạ̣ dvādaśaviṃśopakādhikabalaḥ pūrṇabalaḥ | etat spașțam uktam hillājena |

pañcaviṃśopakān nyūnabalo naștabalo grahah |

pañcavimśsopakabalo hinaviryaḥ prakìrtitạ $\|$ pañcādhikabalo madhyabalaḥ sampürṇavīryakah | daśādhikabalo 'bdeśaphalam jñeyaṃ tribhāgataḥ ||

iti sāmānyapañcavargībalasādhanam ||

6 vargikāmutsthānottha] vargikām utthānottha B N a.c. G; vargikāsu sthānottha K T M 7 madhyamādiḥ] madhyanāḥ dir N 12 hillājena] hillājanena G 16 daśādhika] daśodhika $\mathrm{T}$ || balo 'bdeśa] baloddeśa $\mathrm{N}$; balodbheśa? G

6-7 śrīsūrya ... madhyamādiḥ] TYS 4.40

6 mutsthānottha] $\mathrm{N}$ adds the following gloss in a different hand at the bottom of the page: mut prïti pramado harșa iti kośät harșasthānotthabalam ity arthah. 
[Mercury's] maximum strength by any calculation would amount to eighteen points; [there is] no strength amounting to twenty points. And for other [planets], because their domiciles and exaltations are different [signs], the strength would certainly be less than twenty points.

Concerning this, some [say that] a planet should be understood to have full strength if the total of the strengths [arising from] the five dignities, the twelve dignities, and the places of joy, divided by three, amounts to twenty points. And Yādava says [in Täjikayogasudhānidhi 4.40]:

If the total of the strengths produced by the twelve dignities, the five dignities, and the places of joy, divided by three, is twenty, the planet has full strength. Middling [strength] and so on [should be determined] by proportions of strength.

But enough of digression. For the purpose of knowing the results of periods, then, [a planet] with less than five points of strength is powerless; one whose strength amounts to [exactly] five points has little strength; one whose strength is greater than five [points] is of middling strength; and one whose strength is greater than ten [points] has full strength. But for the purpose of knowing the results of the ruler of the year, [a planet] whose strength amounts to six points has little strength; one whose strength is greater than six points is of middling strength; and one whose strength is greater than twelve points has full strength. This is clearly described by Hillāja:

A planet with less than five points has no strength; one with five points of strength is declared to be of little strength; one with more than five [points of] strength has middling strength; one with more than ten [points of] strength has full strength. The results of the ruler of the year should be known by a threefold division.

This concludes the general arrangement of the five dignities. 
atha khattakhuttakhindakādisammatam sthānadikkālanisargaceșțādṛgbalaṃ nirūpyate | uktaṃ ca samarasiṃhena |

sāmānyabalam ihoktam viśeșam avalokya phalam ūhyam | iti |

tatrādau sthānabale saviśeșapañcavargīcakrasūcanam uktam kutthayoge samarasimhena |

sabalī svagrhatrirāśihaddoccamuśallaheșu vā khețah | iti |

etat spașțaṃ gaṇitapūrvakam uktaṃ tājikamuktāvalyām |

svādhiștādau tarkavedāgninetra-

rūpārdhāni syur gṛhe 'rkoddhṛtāni |

tuñge vedāgnyaśvinas tattadardham

hadde rāmā dvau tadardhāny atặ syuh $\|$

trairāśyutthe dvau tadardhārdhakāni

trairāśyardham syān musallāhasaṃjñe |

yad vā sveștāāātișu dvādaśāṃśā

gehād añgābdhyagnayo 'bdhyagnidasrāḥ \|

rāmāśryabjā netracandrārdhakāni

candrārdhāṃśā rūpapūrvāh krameṇa|

khețe śuddhe saptamāt svādigehāc

cheșe bhādye 'nyatra kalpyo 'nupātaḥ

1 sammataṃ] sthānādisaṃmatam add. G p.c. || dikkāla] dikyala B N G a.c. || nisarga] visarga T $\quad 1-2 \quad$ dṛg] dig G p.c. 6 trirāśi] scripsi; trairāśika B N G K T M \| muśallaheșu] samuśallaheșu B N G || vā khețah]] varișțha K T M 8 netra] netre K T M 10 ardhaṃ] arthaṃ B N G a.c. 12 utthe] usye B N G a.c. || dvau tadardhā] om. N $\quad 13$ ardhaṃ] ardhạ̣ M 14 dvādaśāṃśā] dvādaśāṃśo K T M 19 bhādye] scripsi; bhārddhe B N G K T M

8-210.2 svādhịsțādau ... bhavet] TM 50-53

6 sabalī ... khețah] The reading trairāśika, though supported by all text witnesses, has been emended to trirāśi for metrical reasons, with no change in meaning. 19 bhādye] The emendation is supported by MS TM. 


\subsection{The Sixfold Strength}

Next, the strength by position, direction, time, nature, motion and aspect, approved by Khattakhutta, Khindika and others, is set forth. ${ }^{37}$ And Samarasiṃha says [in the Tājikaśāstra]:

The general strength has been described here; [but] one should ascertain results after examining [the strength] in detail.

\subsubsection{Strength by Position}

Beginning, then, with strength by position, Samarasimha in [treating of] the kuttha configuration [in the Tãjikaśāstra] gives an indication of the detailed scheme of the five dignities:

A planet is strong in its domicile, triplicity, haddā, exaltation or musallaha.

This is described clearly, along with calculations, in Täjikamuktāvali [50-53]:

In [a division belonging to the planet] itself, a great friend, and so on, [the values] for domicile will be six, four, three, two, one, and a half, divided by twelve; for exaltation, four, three, two, and consecutive halves; then, for haddā, they will be three, two, and [consecutive] halves of that; for [the strength] produced by triplicities, two, and the halves and halves of that; for musallaha, it will be half of [the strength of] the triplicity. Or else, in [the scheme consisting only of the planet] itself, friends, and enemies, the twelfths of points [for these dignities, reckoned] in order from the domicile, are: six, four, three; four, three, two; three, two, one; two, one, and a half; one, a half, and a [quarter] fraction, if, when the planet has been subtracted from the seventh from its own domicile, the remainder falls in its domicile and so forth; [if it falls] elsewhere, proportions should be applied.

37 While these 'six strengths' (șadbala) play an important part in classical Indian astrology (see, e.g., Jätakakarmapaddhati 3), the classification is not used in the Greek or Perso-Arabic traditions. 
adhișțādigrahādibhyo balam yad iha sādhitam |

tattaddrñmānanighnam tat șaștibhaktam sphuțam bhavet || iti |

pañcadhāmaitryāṃ balavibhāgata etāny an̉kāni dvādaśoddhṛtāni balam

gṛham uccam haddā trairāśikaḥ musallahạ̣

\begin{tabular}{llllll}
\hline sviyavarge & 6 & 4 & 3 & 2 & 1 \\
adhimitravarge & 4 & 3 & 2 & 1 & $\|$ \\
mitrasya varge & 3 & 2 & 1 & $\|$ & $\mid$ \\
samasya varge & 2 & 1 & $\|$ & $\mid$ & $=$ \\
śatruvarge & 1 & $\|$ & $\mid$ & $=$ & - \\
adhiśatruvarge & $\|$ & $\mid$ & $=$ & - & '\| \\
\hline
\end{tabular}

dvidhā maitryām vā balacakram

\section{svasya varge mitravarge śatruvarge}

\begin{tabular}{llll}
\hline grham & 6 & 4 & 3 \\
uccam & 4 & 3 & 2 \\
haddā & 3 & 2 & 1 \\
trairāśsikạ̣ & 2 & 1 & $\|$ \\
musallahạ̣ & 1 & $\|$ & $\mid$ \\
\hline
\end{tabular}

atra tarkavedādyañkāni dvādaśoddhṛtāni rūpakalādikaṃ balaṃ bhavati | athātra svag̣̣he pūrṇam balam | duraṣphe svagṛhanagabhagaḥ ity ukteh

\footnotetext{
1 adhīṣțādi] scripsi; abhīṣtādi B N G K T M 3 vibhāgata] vibhāgah K T M || vibhāgata ... balam] om. G $\quad 7$ |] || B G 8 |] || B G $\|=$ ]'|| B;'|| G 9 1] om. T || ||] om. T || |] om. T $\|=$ ]'6 (?) || B;'|| G; om. T || - '3 || B; 3 ||| G; om. K T M $10=$ ]'|| B;'|| G || -]'3 || B;

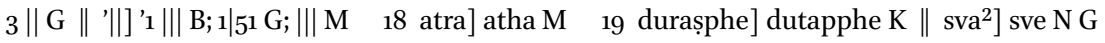
a.c. || gṛha] graha B N G || bhagaḥ] bhāga B G K T M

1 adhīṣtādi] The emendation is supported by MS TM1. 3 pañcadhāmaitryāṃ] The following table is omitted by $\mathrm{N}$. The remaining text witnesses abbreviate some words. Fractional values appear to be denoted by different systems in the text witnesses. In the majority system adopted here, a simple vertical line denotes a quarter; a horizontal line, a sixteenth-part; and a vertical line preceded by an apostrophe, a sixty-fourth-part. $\quad 11$ dvidhā] The following table is omitted by N K T M, while B G abbreviate some words.
} 
The strength thus established from planets [occupying the divisions of their] great friends and so on will be exact when multiplied by the respective measure of aspect [strength] and divided by sixty.

These numbers divided by twelve are the strength according to the distribution of strength in the fivefold friendship [scheme]:

\begin{tabular}{llllll}
\hline & Domicile & Exaltation & Hadda & Triplicity & Musallaha \\
\hline Own division & 6 & 4 & 3 & 2 & 1 \\
$\begin{array}{l}\text { Great friend's } \\
\quad 4\end{array}$ & 3 & 2 & 1 & $1 / 2$ \\
$\quad$ division & & & & & \\
Friend's division & 3 & 2 & 1 & $1 / 2$ & $1 / 4$ \\
Neutral division & 2 & 1 & $1 / 2$ & $1 / 4$ & $1 / 8$ \\
Enemy's division & 1 & $1 / 2$ & $1 / 4$ & $1 / 8$ & $1 / 16$ \\
Great enemy's & $1 / 2$ & $1 / 4$ & $1 / 8$ & $1 / 16$ & $1 / 32$ \\
$\quad$ division & & & & & \\
\hline
\end{tabular}

Another table of strength by twofold friendship:

\section{Own division Friendly division Inimical division}

$\begin{array}{llll}\text { Domicile } & 6 & 4 & 3 \\ \text { Exaltation } & 4 & 3 & 2 \\ \text { Hadd } \bar{a} & 3 & 2 & 1 \\ \text { Triplicity } & 2 & 1 & 1 / 2 \\ \text { Musallaha } & 1 & 1 / 2 & 1 / 4\end{array}$

Here, the numbers six, four and so on, divided by twelve, is the strength in units and [sexagesimal] fractions. Now, [a planet's] strength here is full in its own domicile; [but as seen] from the statement 'In [the configuration] duruhpha, occupying the seventh sign from its domicile', a planet is pow- 
svag̣̣hāt saptame rāśau graho nirbalah | antare trairāśikam uccabalavaj jñeyạ ||

tatrārkacandrayor ekam eva svagṛham ato na saṃdigdham | bhaumādīnāṃ tu svagṛhadvayasadbhāvāt tatsaptamasyāpi dvaividhyāt katham | atra balānayanopāya ucyate | bhaumādiṣu cāravaśāt nikațasthitam eva svag̣̣haṃ svag̣̣ham na tu dūrasthitam iti sampradāyayuktir iti | atha gṛhaṃ svag̣̣hasaptamād viśodhya śeșaṃ șaḍadhikaṃ cet dvādaśaśuddham no ced yathāsthitam eva sthāpyam | tatas tasyāṃśāḥ șaḍbhaktāḥ kalādi balam syād iti ||

atropapattị̣ | svag̣̣haprārambhe pūrṇaṃ triṃśatkalātmakaṃ balaṃ tatsaptamārambhe śūnyam antare 'nupātah | yadi rāśișaṭkāṃśaị 18o pūrṇam balam 3 o labhyate tadeștena kim iti | atra guṇaharayos triṃśatāpavarte kṛte guṇasthāne rūpam bhājakasthāne șaḍ ity upapannam | evam adhimitragrahasya gṛhe pūrṇam balam 20 adhimitrag̣̣hāt saptame śūnyam | tatrādhimitrag̣̣hastham graham adhimitrasaptamag̣̣hād viśodhya śeșam șaḍadhikaṃ dvādaśaśuddhaṃ no ced yathāsthitam eva sthāpyaṃ tasyāṃśā navabhaktāḥ kalādi svādhimitrag̣̣habalaṃ syāt ||

atropapattir anupātena | yadi rāśișațkāṃśaiḥ 18o pūrṇaṃ balaṃ 20 tadeștena kim iti | atra guṇaharayor viṃśatibhir apavarte kṛte guṇasthāne rūpạ̣ bhājake navety upapannam | evaṃ grahabale svasvaparamabalena svasvasaptamagṛhena ca pūrvavad anupātayuktyā sopapattikaṃ balaṃ sādhyam | svoccabalaṃ tv anupātena prāg ānītam eva | adhimitrādyucce uktavad anupātena balạ̣ sādhyam | uccarāśyabhāve svoccabalam eva kartavyam ||

3 eva] eka B N G a.c. 4 saptamasyāpi] samasyāpi B N G 6 svagṛham $]$ om. N K T M 7 viśodhya] viśodhyam G T || șaḍadhikaṃ] șaḍaiva'dhikaṃ B N G 9 g̣̣ha] graha N G 13

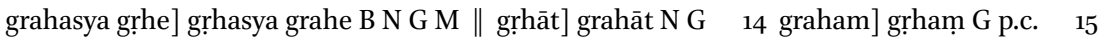
-tam eva sthāpyaṃ] om. B N G 16 balaṃ] vahaṃ G 18 guṇaharayor] guhaṇarayor N 20 gṛhena] grahena B 21 adhimitrādy] adhitrādy N

38 The source of this quotation is not known. As given, it appears to form part of a line in the syllabic sragdharā metre. However, the orthography of Tājika technical terms is quite fluid, and a change from durasphe to duraphe (both variants being common) would make it qualify as the first or third quarter of a stanza in the moraic ārya metre favoured by Samarasiṃha in his Tãjikaśāstra. The name (from Arabic dụf 'weakness') refers to the last of the 16 Tàjika yogas; cf. section 3.16.

As each of the seven planets has only one sign of exaltation, five signs of the zodiac 
erless in the seventh sign from its domicile. ${ }^{38}$ In the interval [the strength] should be understood [by] the rule of three, as with exaltation strength.

In that regard, the sun and the moon have only one domicile [each]; hence there is no ambiguity. But since the [planets] beginning with Mars have two domiciles [each], and the seventh from those are also twofold, how [should we proceed]? [In reply] to this, the method for calculating strength is stated [as follows]: the domicile that is close to Mars and so on in their motions is considered to be the [relevant] domicile, and not the one that is far away: this is the reasoning [approved by] tradition. Subtracting the sign [occupied] from the seventh from the [planet's] domicile, then, if the remainder exceeds six, it should be subtracted from twelve; if not, it should be taken as it is. Then, its points divided by six will be the strength in points and so on.

This is demonstrated [as follows]: at the beginning of [a planet's] own domicile, [its] strength is full, comprising thirty points; at the beginning of the seventh [sign] from it, it is nil; in the interval, [strength is calculated by] proportion. If by the 180 degrees of six signs a full strength of 30 is obtained, then how much [is obtained] by the [position] sought? Here, when the multiplier and divisor have been reduced by thirty, one unit is obtained in the place of the multiplier and six in the place of the divisor. Likewise, in the domicile of a great friend, the full strength is 20 ; in the seventh from the domicile of the great friend, [the strength is] nil. Then, subtracting the planet occupying a great friend's domicile from the seventh house from that of the great friend, the remainder, [if] exceeding six, is subtracted from twelve; if not, it should be taken as it is. Its points divided by nine will be the strength of a great friend's domicile in points and so on.

This is demonstrated by proportions: if by the 180 degrees of six signs a full strength of 20 [is obtained], then how much [is obtained] by the [figure] sought? Here, when the multiplier and divisor have been reduced by twenty, one unit is obtained in the place of the multiplier and nine in the place of the divisor. Thus in [the matter of] planetary strength, the correct strength is to be found by the rule of proportion from the respective maximum strength and the respective seventh house, as above. The exaltation strength has already been calculated by proportion; the strength in the exaltation of a great friend and so on should be found by proportion as described [above]. In the absence of an exaltation sign, the [planet's] own exaltation strength should be worked out. ${ }^{39}$

remain in which no planet is exalted. Balabhadra is addressing a scenario where the planet under consideration occupies one of these five signs. 
atha haddādreșkāṇanavāṃśānāṃ saptame nairbalyam iti vacanābhāvād aṃśair evānupātaḥ | tad yathā | grahasya vartamānahaddārambhe balārambhạ haddāmadhye paramaṃ balam 15 haddāsamāptau balaṃ śūnyam | tatra grahahaddābhuktabhogyayor alpahaddāṃśāḥ pañcadaśagunāḥ vartamānahaddārdhāṃśabhaktāḥ svahaddābalaṃ syāt | atropapattir anupātena | yadi vartamānahaddārdhāṃśaị pañcadaśa kalā labhyante tadā grahahaddābhuktabhogyayor alpāṃśaị̣ kim ity upapannam ||

atha svadreșkāṇaprārambhe balopacayah pañcamāṃśasamāptau pūrṇaṃ balaṃ 10 daśāṃśasamāptau śūnyạ̣ balaṃ | tatra grahavidyamānadreșkāṇabhuktabhogyayor alpam aṃśādi dviguṇaṃ kalādi svadreșkāṇabalaṃ syāt | atropapattị | yadi pañcabhir aṃśair daśakalāmitam balam tadeșțena kim | atra pañcabhir apavarte kṛte harasthāne rūpaṃ guṇasthāne dvayam ity upapannam \|

atha musallahārambhe balārambhạ madhye pūrṇam balam 5 ante śūnyaṃ | tatra grahavidyamānamusallahabhuktabhogyayor alpam aṃśādi triguṇitạ̣ svamusallahabalaṃ syāt | atropapattị̣ | yadi musallahārdhena catvāriṃśatkalādhikenaikāṃśamitena pañcakalāmitaṃ balaṃ tadeșțena kim iti | atra bhājakāt triguṇo guṇakaḥ ato 'ṃśādi triguṇikṛtyam ity upapannam $\|$

2-8 grahasya ... sva] om. B N G a.c. 4 graha] g̣̣ha G 7 bhuktabhogyayor alpāṃśaih] bhuktāṃśaị̣ G 8 balopacayah] phalopacayaḥ B N K T M; phalepacayaḥ G a.c. \| pañcamāṃśasamāptau] paṃcamāṃsasarāṃśai B; paṃcamāṃsasarāśai N G a.c. 9 10] 20 G p.c. T 10 svadreșkāṇa] om. B N G a.c. K 12 tadeșțena] tadaikena B N G \| hara] guṇaka G p.c. \| rūpaṃ guṇasthāne] om. B N G 14-19 atha ... upapannam] om. B N G a.c. 15 graha] gṛha G $\quad 16$ triguṇitaṃ] caturguṇyam G $\quad 17$ catvāriṃśat] caśatvāriṃśat K $\quad 17-18$ catvāriṃśat ... kṛtyam] sapādāṃśamite ca 1|15 G 18 iti] om. G || bhājakāt ... kṛtyam] bhājakāc caturguṇo guṇaka $\mathrm{a}^{* * * *}$ ṇakṛtam G $\|$ kṛtyam] kṛtam M

2-8 grahasya ... sva] From the context it seems likely, but not certain, that this passage is a later interpolation. G notes in a different hand in the margin: truțah. 10 svadreșkāna] From the context it seems likely, but not certain, that this passage is a later interpolation. 14-19 atha ... upapannam] From the context it seems likely, but not certain, that this passage is a later interpolation. In $\mathrm{G}$ it has been added to the bottom of the page, and damage to one corner has obliterated about seven akșaras.

40 Over the next three paragraphs, several sentences and stray phrases have been enclosed between \{curly brackets\}. These represent text that is not present in the earliest text witnesses and which from the context seems likely not to have formed part of the original Hāyanaratna but to have begun as glosses on a difficult passage. I have nevertheless chosen to include rather than exclude these passages, as they do not contradict the reasoning of the surrounding text. 
Now, as there is no statement to the effect that [a planet suffers] loss of power in the seventh from [its own] hadda, decan or ninth-part, the proportion is [calculated] by degrees only, as follows: ${ }^{40}$ \{the strength begins with the beginning of the current hadda [occupied by] the planet; the maximum strength [of] 15 [points] is at the middle of the hadd $\bar{a}$; and the strength is nil at the end of the haddā. Therefore, of the parts elapsed and remaining to the planet in the hadd $\bar{a}$, the lesser degrees of the haddā multiplied by fifteen and divided by half the degrees of the current hadda will be the [planet's] own strength of hadd $\bar{a}$. This is demonstrated by proportions: if by half the degrees of the current hadda fifteen points are obtained, then how much is obtained by the lesser degrees out of the parts elapsed and remaining to the planet in the haddā?

Next, $\}$ the [decan] strength increases from the beginning of the [planet's] \{own\} decan; the full strength [of] 10 [points] is at the completion of the fifth degree; and the strength is nil at the completion of the tenth degree. Therefore, of the parts elapsed and remaining to the planet in its current decan, the lesser degrees and so on multiplied by two will be the [planet's] \{own decan\} strength in points and so on. This is demonstrated [as follows]: if by five degrees a strength of ten points [is obtained], then how much [is obtained] by the [position] sought? Here, when [the multiplier and divisor] have been reduced by five, one unit is obtained in the place of the divisor and two in the place of the multiplier.

\{Next, the [musallaha] strength begins at the beginning of the musallaha; the full strength [of] 5 [points] is at the middle; [and the strength is] nil at the end [of the musallaha]. Therefore, of the parts elapsed and remaining to the planet in its current musallaha, the lesser degrees and so on multiplied by three will be the [planet's] own musallaha strength in points and so on. This is demonstrated [as follows]: if by half the musallaha, amounting to one degree and forty minutes, a strength of five points [is obtained], then how much [is obtained] by the [position] sought? Here, the multiplier is three times the divisor; therefore, [the answer] is obtained when the degrees and so on are multiplied by three. $\}^{41}$

41 Text witness $\mathrm{G}$ consistently uses a factor of 4 rather than 3 throughout this passage and explicitly states that half a musallaha extends over $1^{\circ} 15^{\prime}$ (rather than $1^{\circ} 4 \mathrm{O}^{\prime}$ ). The musallaha would thus be equated not with the ninth-part or navāmśa of $3^{\circ} 20^{\prime}$, but

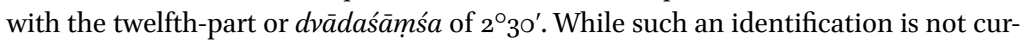
rently known from any other Tajjika work, the doctrine of twelfth-parts is an ancient one, going back to Babylonian times and present in both Greek and Arabic sources, and this identification could represent a deliberate attempt to incorporate it in the five-dignity scheme. 
evam anupātenādhimitrādidreșkāṇabalam | pūrvoktaparamabalena grahasya haddādreșkāṇamusallahabalaṃ sādhyam | evaṃ svādinavāṃśe svādihaddāyāṃ tattadaṃśair anupātāt phalaṃ jñeyam | tatra haddāyāṃ paramaṃ balaṃ kalāḥ 15 musallahe paramaṃ balaṃ kalāḥ 5 | atha evaṃ sarvabalaikyaṃ grahopari anyeșāṃ grahānāạm yā dṛ̦țayaḥ samāgatās tadaikyena guṇitạ̣ șașțibhaktaṃ sphuțaṃ syāt ||

evaṃ saviśeșapañcavargīcakranirūpaṇānantaram anyat sthānabalam uktam tatraiva samarasiṃhena|

yo lagne kendre vā tannikațe vātha vīkșate lagnam | purușā gaganād yāvat trit̄̄yabhavane striyo 'pi navamāntam \| puṃkhețāh puṃāáau strīrāsau strīgrahā balinaḥ | sarveșām strīpumsạ̄̄ sthirarāśau vā bhavanti te balinaḥ || iti |

etat spașțaṃ ganiitapūrvakam uktaṃ muktāvalyām |

lagnakendratadupasthitagrahe rūpakārdhacaraṇonmitaṃ balam | strīṣu rūpam avaner navamāntaḥ pumsu bhāvaphalatoparageșu \| sthirarāśau sarveșām pumstrīrāśau pumañganākhyānām || iti |

atra lagne grahah pūrṇavīryaḥ kendre 'rdhavīryah paṇapharāpoklimayoś caraṇavīryaḥ | tatra pūrṇaṃ balaṃ șașțikalātmakam ardhaṃ trimśatkalāḥ caraṇaḥ pañcadaśakalāḥ \||

1-2 pūrvokta ... balaṃ] om. B N G 2 sādhyam] bodhyam B 3 tatra] tattad B; tata N G 4 balaṃ² $^{2}$ om. K T M \| atha] om. B N G 9 vā] om. B $\quad 11$ khețāḥ] khecarāḥ G p.c. 12 sarveșāṃ strīpumsaāṃ] om. B N G K T \|| te] om. B 14 lagna] gna N G a.c. 15 rūpam avaner] rūpabhavaner B N G 16 pum] om. B N G a.c. 18 caraṇa] ca pürṇa N G a.c. \| triṃśat] tryaṃśat B; aṃśat N G

14-16 lagna ... -ākhyānām] TM 47-48

18 trimśat] The reading of $\mathrm{N} \mathrm{G}$ is another instance of confusion of the characters $a$ and trya (as seen in B) in northern-style Devanāgarī.

42 In the version supported by the three earliest text witnesses (B N G), the foregoing two sentences read as a single sentence: 'Thus the strength of [a planet in] the decan of a great friend and so on should be found by proportion.' 
Thus the strength of [a planet in] the decan of a great friend and so on [is found] by proportion. A planet's strength of haddā, decan and musallaha should be found from the maximum strength described above. ${ }^{42}$ Thus one should understand the result [of a planet] in its own and other ninth-parts, and in its own or other haddās, by proportion from the respective degrees. As to that, the maximum strength in the hadda is 15 points, and the maximum strength in the musallaha is 5 points. Then, the total of all such strength, multiplied by the total [strength] of the aspects cast by other planets on the planet [under consideration] and divided by sixty, is the exact [strength].

Following this definition of the detailed scheme of the five dignities, a different strength by position is described by Samarasimpha in the same [Tājikaśāstra]:

[The planet] that, [placed] in the ascendant or an angle, or in [a house] approaching them, ${ }^{43}$ aspects the ascendant; male [planets in the interval] from the tenth house to the third, and female [planets from the fourth house] up to the ninth; male planets in male signs, and female planets in female signs, are strong; or for all of them, male or female, they are strong in a fixed sign.

This is described clearly, along with calculations, in [Tājika]muktāvali [4748]:

A planet in the ascendant, an[other] angle, or [a house] approaching one has a strength of one, a half or a quarter unit, respectively. Female [planets] have one unit between [the angle of] the earth and the ninth [house]; male [planets] are fruitful in the following houses. All [planets get one unit] in a fixed sign, those called male and female in male and female signs, [respectively].

Here, a planet in the ascendant has full strength; in an[other] angle, half strength; in a succedent or cadent house, a quarter strength. ${ }^{44}$ Full strength, then, comprises sixty points; half, thirty points; a quarter, fifteen points.

44 Balabhadra interprets the words nikața and upasthita (used in the foregoing quotations from Samarasiṃha and the Tãjikamuktāvali, respectively) not in the dynamic sense of 'approaching' - that is, succedent - but in the static sense of 'near', which would apply equally to succedent and cadent houses. Such an interpretation is alien not only to Greek and Perso-Arabic astrology, but even to pre-Islamic Indian tradition, which distinguishes between the strength of these two types of houses (see, e.g., Brhajjātaka 1.17-18). 
atha lagnasame grahe pūrṇaṃ balaṃ | dvādaśasaṃdhivirāmavikalāto lagnabhāvaprārambhạ̣ | tatas tadvirāmaṃ yāvat phalopacayaḥ | prathamabhāvavirāmavikalātaḥ prathamasaṃdhivirāmaṃ yāvad bhāvaphalāpacayạ̣ | antarasthe grahe 'nupātaḥ kāryaḥ | sa cānupātaḥ pūrvaṃ grahasaṃdhyantaram kāryam ityādinā bhāvaphalānayanārtham kṛta eva | ato lagnasthagrahasya bhāvaphalam eva balaṃ | kendrasthagrahasya bhāvaphalārdham eva balaṃ | paṇapharāpoklimasthagrahasya bhāvaphalacaturthāṃśo balam iti $\|$

atha strīgrahāṇāṃ caturthādiṣaḍbhāveșu balavattvokteh pūrvayuktyā caturthādiṣaḍbhāvasthānāṃ strīgrahāṇāṃ bhāvaphalam eva tatratyam balam | evaṃ puruṣagrahānām api daśamādiṣaḍbhāveșu sthitānāṃ bhāvaphalam eva balam iti \|

atha sthirarāśisthagrahabalam | tatra rāśyārambhe balopacayah pañcadaśāṃśaị pūrṇaṃ balaṃ rāśyante śūnyam | ato grahasya rāśipūrvārdhe sthitasya bhuktāṃśāḥ rāśyuttarārdhe sthitasya grahasya bhogyāṃśāś caturguṇā balam | atropapattị | yadi pañcadaśāṃśaih pūrṇaṃ balaṃ 6o labhyate tadā sthirarāśisthitagrahabhuktabhogyair aṃśaiḥ kim | atrobhayoh pañcadaśabhir apavarte kṛte aṃśáś caturguṇāh kāryā ity upapannam | evaṃ viṣamasamarāśigānāṃ puṃstrīgrahāṇāṃ sthirarāśisaṃsthagrahabalavad balaṃ jñeyaṃ | iti sthānabalam ||

2-3 tatas ... vikalātaḥ] om. B N G 3 phalāpacayah] phalopacayaḥ M 4 kāryah] om. K T M 5 krta] scripsi; krtam B N G K T M 6 balam] phalam N G a.c. $\quad 6-7$ kendrastha ... balaṃ] keṃndrasthagrahasya bhāvaphalārdham eva balaṃ add. B 13 rāśisthagrahabalam] rāśosthagrahacalam N $\quad 14$ sununyam] balam add. K T M 15 sthitasya ${ }^{1}$ ] grahasya add. B N G p.c. || grahasya] om. B N G 17 sthirarāśi] sthirarāśirarāši G \| graha] om. K T 18 aṃśáś] tryamśāś K T M 19 sthira] strī K M; om. T 20 graha] guru B N G

4-5 graha ... kāryam] Cf. TM 17

18 aṃsáśs] The reading of K T M is another instance of confusion of the characters $a$ and trya in northern-style Devanāgarī (this time in reverse). 
Now, a planet exactly on the ascendant has full strength; [but] the ascendant house commences from the second of arc marked by the junction [following] the twelfth house. From that [junction] up to the [cusp] marking that [first house], results increase; and from the second of arc marked by [the cusp of] the first house up to that marking the junction [following] the first [house], results of the house decrease. When the planet occupies the interval, proportion should be applied; and that proportion has been set forth above in the context of calculating the results of a house, with the words 'The distance between the planet and the [house] junction should be found' and so on. ${ }^{45}$ Therefore, for a planet placed in the ascendant, its strength is the [numerical] house result itself; for a planet placed in an[other] angle, its strength is half its house result; for a planet placed a succedent or cadent [house], its strength is one fourth of its house result. ${ }^{46}$

Next, because female planets are said to be strong in the six houses beginning with the fourth, by the reasoning above, the [numerical] house result of female planets placed in the six houses beginning with the fourth is itself [their] strength arising from that placement. Similarly, for male planets placed in the six houses beginning with the tenth, the [numerical] house result itself is [their] strength.

Next, the strength of planets occupying a fixed sign. Concerning that, the strength increases from the beginning of the sign; after fifteen degrees, the strength is full; at the end of the sign, it is nil. Therefore, for a planet placed in the former half of the sign, the degrees traversed, and, for a planet placed in the latter half of the sign, the degrees remaining, multiplied by four, is the strength. This is demonstrated [as follows]: if by fifteen degrees the full strength [of] 6o [points] is obtained, then how much [is obtained] by the degrees traversed by or remaining for the planet occupying the fixed sign? Here, when both [multiplier and divisor] have been reduced by fifteen, the degrees should be multiplied by four: thus [the answer] is obtained. Similarly, the strength of male and female planets occupying odd and even signs, [respectively], should be understood in the manner of the strength of planets occupying a fixed sign. This concludes the strength by position.

\footnotetext{
45 Presumably Balabhadra has in mind the stanza from Täjikamuktāvali 17, quoted in section 1.9, in which case this is not an exact quotation.

46 Cf. note 44 .
} 
atha digbalam uktam tatraiva |

navamasahajașașțhāngāyaputrāntyabhasthā

dyumaṇita iha khețā digbalädhyā bhaveyuh | iti |

atra sūryādīnāṃ navamādisthāne pūrvoktayuktyā bhāvaphalatulyam eva balaṃ jñeyam | idam eva prathamam harṣabalaṃ samarasiṃhenoktam | iti digbalam \|

atha kālabalam | tatra samarasiṃhaḥ |

gurumandau yadi paścimarātrau śukrendubhūsutāḥ sāyam |

udayanti tadā balino naragrahāś cāhni naktam apare ca \|

atrārkāt saptamalagnodayah kālaḥ sāyaṃśabdavācyah | tatra candra- 10 bhaumau pūrṇabalau 6o | atrārkāc chukrạ̣ saptamah kadāpi na sambhavaty ato 'tra saptamaśabdaḥ paramāntaravācī jñeyah | atạ̣ sūryaśukrayoḥ paramāntarāṃśaị̣ pañcāśatsaṃkhyair balạ̣ sādhyam | uktạ̣ ca muktāvalyām |

raveh saptame candrabhaumau baläḍhyau

khapañcāṃśatulyāntare daityamantrī | iti |

2 bhasthā] masthā B N G 3 balāḍhyā] balādyā B N G a.c. K T M $\quad 5$ idam] ayam B N G K T 9 balino] calino N 12 paramāntara] maramāṃtara B 15 balāḍhyau] balādyau N G a.c. 16 tulyāntare] tūlāṃtare K M

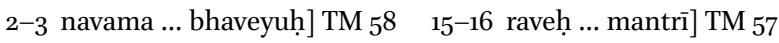




\subsubsection{Strength by Direction}

Next, the strength by direction is described in the same place [Täjikamuktāvali 58]:

Occupying the ninth, third, sixth, first, eleventh, fifth and twelfth place, [respectively], the planets [reckoned] from the sun become endowed with strength by direction.

Here, by the [same] reasoning [as] above, the strength of the sun and other [planets] in the ninth and other places should be understood to equal the [numerical] results of the house. This itself is the first strength of joy described by Samarasimha. This concludes the strength by direction.

\subsubsection{Strength by Time}

Next, the strength by time. Regarding that, Samarasimha [says in the Tājikaśāstra]:

If Jupiter and Saturn rise [heliacally] at the end of night, and Venus, the moon and Mars in the evening, then they are strong; also [strong are] male planets in the day, and the others, at night. ${ }^{47}$

Here, the phrase 'in the evening' denotes the time when the seventh cusp from the sun rises. ${ }^{48}$ The moon and Mars then have full strength [of] 6o [points]. Concerning this, it is never possible for Venus to be [in] the seventh from the sun; therefore, the word 'seventh' should be understood here to denote maximum elongation. Thus, the strength should be established from the maximum elongation of Venus from the sun, amounting to fifty degrees. And it is said in [Tājika]muktāvali [57]:

The moon and Mars are strong in the seventh from the sun, Venus at a distance of fifty degrees.

47 This sentence, clearly based on Sahl's somewhat defective account, conflates three similar but separate ways of dividing the planets into two groups: diurnal and nocturnal sect, gender, and superior/inferior position relative to the sphere of the sun; see Gansten 2018. For Mars to rise heliacally in the evening is astronomically impossible.

48 That is, the ecliptical point opposite the sun. This is not correct: Balabhadra mistakes the heliacal rising intended by Samarasiṃha (following Sahl) for acronychal rising, when a planet appears opposite the sun and thus rises as the sun sets. As Venus can never rise acronychally, Balabhadra is forced to adopt a highly contrived interpretation of Samarasiṃha's statement. 
sūryatulyatve sarve 'pi nirbalāh | atha balānayanam | sūryasya candrabhaumayoś cāntaraṃ ṣaḍunaṃ sthāpyam | tadaṃśās tribhaktā balạ̣ bhavet | atropapattir uccabalavat | sūryaśukrayoś cāntaram pañcāśadaṃśamadhye sthāpyam | tadanantaram etadamisaạh șaḍgunāḥ pañcabhaktāḥ śukrabalam syāt | atropapattị̣ | yadi pañcāśadaṃśaị̣ șașțikalā labhyante tadeșțena kim iti | ubhayor daśabhir apavarte kṛte guṇakạ̣ șaḍ bhājakạ̣ pañcety upapannam $\|$

atha jīvaśanyor ardharātrānantaraṃ balārambhaḥ | tṛtīyapraharānte balaṃ pūrṇaṃ | caturthapraharānte balạ̣ śūnyaṃ | atạ sūryād rātrimānam ānìya yady ardharātrānantaram ișțakālas tadā tasminn ardharātrah śodhyah | yadi tṛtiyapraharottaram ișțakālaḥ sa rātrimānamadhye śodhyạ̣ | śeșaṃ șaștiguṇam praharamānena bhaktaṃ labdhaṃ guruśanibalam ||

atha divasādigrahabalam | tatra lagnamadhye raviṃ viśodhya yady avaśeșaṃ tryūnaṃ tadā tadrāśyādikaṃ viṃśadguṇaṃ balam | adhikaṃ ṣaṭcyutạ̣ vidheyaṃ śeșaṃ rāśyādi viṃśadguṇaṃ puṃgrahāṇāṃ balaṃ bhavati | puṃgrahāṇāṃ ravyūnalagne șaḍadhike tu na balam | evaṃ ravyūne lagne șạ̣ūne sati strīgraheșu na balam | șạ̣adhikam șaḍūnaṃ navādhikaṃ dvādaśatyaktam avaśeșaṃ viṃśatiguṇaṃ strīgrahavīryam bhavati | yato dinaniśoḥ puṃstrīprābalyam uktaṃ saṃdhau tu virāmaḥ | etat spașțam uktam muktāvalyām |

4 etad] eva tad K T M $\quad 8-10$ ardha ... yady] om. B N G a.c. 9 atah] atha K T M 10 ardharātrānantaram] ardharātryanaṃtaram B N G a.c. 12 balam] lavaṃ G 15 grahāṇāṃ] grahīṇāṃ N 16 adhike] adhikena G p.c. 17 graheșu] scripsi; gṛheșu B N G K T M ॥ balam] calaṃ N || adhikaṃ] adhike K T M || navādhikaṃ] vādhikaṃ M 18 graha] g̣̣ha N G \| vìryaṃ] cinnaryam $\mathrm{N}$

49 This statement conflicts with what will be said below in the context of strength by motion; cf. note 53 .

50 A watch (prahara) is a quarter of the day or, as in this case, night, beginning at sunset. The third watch thus commences at midnight and lasts for half of the time between midnight and the following sunrise. 
When [their longitude is] equal to [that of] the sun, all [planets] are powerless. ${ }^{49}$ Now, calculating the strength: the distance between the sun and the moon or Mars should be established [so that it is] less than six [signs]: those degrees, divided by three, will be the strength. This is demonstrated in the same way as exaltation strength. Then the distance between the sun and Venus, out of the fifty degrees [possible], should be established; thereafter, these degrees multiplied by six and divided by five will be the strength of Venus. This is demonstrated [as follows]: if by fifty degrees sixty points are obtained, then how much [is obtained] by the [elongation] sought? When both [places] have been reduced by ten, the multiplier is six and the divisor, five: thus [the answer] is obtained.

Next, the strength of Jupiter or Saturn begins immediately after midnight; at the end of the third watch, the strength is full; at the end of the fourth watch, the strength is nil. Therefore, after one has calculated the duration of night from [the position of] the sun, if the time sought closely follows midnight, then midnight should be subtracted from that [time; but] if the time sought falls after the third watch, that [time] should be subtracted from the duration of night. The remainder multiplied by sixty and divided by the duration of a watch gives the strength of Jupiter or Saturn. ${ }^{50}$

Next, planetary strength by day and so forth. Concerning this, if, after the sun has been subtracted from the ascendant, the remainder is less than three [signs], then those signs and so on multiplied by twenty is the strength. ${ }^{51}$ [If the remainder is] greater [than three signs], it should be subtracted from six. The remainder in signs and so on, multiplied by twenty, is the strength of the male planets. But if the sun subtracted from the ascendant yields more than six [signs], the male planets have no strength; similarly, if the sun subtracted from the ascendant yields less than six [signs], there is no strength for the female planets. [If the number of signs is] greater than six [it should be made] less by six; [if it is] greater than nine, [it should be] subtracted from twelve: the remainder multiplied by twenty is the strength of the female planets, because male and female planets have been said to be powerful by day or night, [respectively]; but [their strength] ceases at the junction [of day and night]. This is described clearly in [Täjika]muktāvali [54]:

$5^{1} \quad$ In other words, the day strength would be considered full not at true midday (when the sun culminates), but when the point $90^{\circ}$ ahead of the sun in the ecliptic rises, which may occur either before or after noon - a curiously counter-intuitive definition. 
arkonalagne cayatas trirāśim yāvat paratrāpacayena rūpam | pumstve 'nyakhețeșu cayān navāntam șaḍhhāt paratrāpacayena vedyam ||

ayam arthaḥ | arkonalagne trirāśim yāvac cayato vṛddhito rūpam balam | trirāśito 'gre apacayena rūpam puṃkhețeșu balam | anyakhețeșu strīgraheșu saptamān navāntaṃ yāvad rūpaṃ balam | aparatra daśamāt dvādaśāntam apacayena rūpaṃ balaṃ jñeyam ity arthah | iti kālabalam ||

atha nisargabalam | tatra nisargabalam uktam tājikapradīpe |

rūpasya saptamāmesso balaṃ bhavet sūryaputrasya | taddvyādigunam bhaumajñagurusitendvarkajaṃ nisargaṃ syāt ||

iti nisargabalam \|

atha ceștābalam | samarasiṃhah |

mandagatir aśĭghragatiś cāvakrah krūradrgrahitah |

krūrāyukto balavān śubhayutadṛțtạ̣ kṛtābhyudayaḥ \|

sūryasya caikabhāge | iti |

1 cayatas] yatas B N G a.c.; cayates T \|| paratrāpa] paracāpa B N 2 puṃstve 'nya] puṃstvanya B N G K T || cayān navāntaṃ] cayān nacāṃtaṃ N; cayan navāntạ̣ K T; ca yatnavāṃs tạ̣ M || vedyam] vidyāt M 3 vṛddhito] vṛddhato B N G a.c. \| balam] om. B N G a.c.; jñeyam add. G p.c. 4 puṃkhețeșu] puṃścețeșu N \| graheșu] gṛheșu B N 5 dvādaśāntam] dvādaśāntaraṃ $\mathrm{G}$ p.c. $\quad 11$ samarasiṃhaḥ] samasiṃhạ̣ $\mathrm{N} \mathrm{G}$ a.c. $\quad 13$ yuta] śyuta $\mathrm{N}$

1-2 arkona ... vedyam] TM 54

$5^{2}$ In other words, the strength of Mars is $2 / 7$ of a unit; that of Mercury, $3 / 7$, etc., making the total strength of the seven planets 4 units. This idea seems to originate in pre-Islamic India rather than with any Arabic-language source; cf. Jätakakarmapaddhati 3.19. The sequence of the planets in increasing order of strength is the two malefics, the neutral Mecury, the two benefics, and the two luminaries. 
The ascendant being made less by the sun, by increase up to three signs and by decrease on the other side, is one unit when [the planet] is male. For the other planets, it should be understood by increase from six signs up to nine and by decrease on the other side.

The meaning is as follows: the ascendant being made less by the sun, the strength up to three signs is one unit by increase, [that is], by increment. After three signs, the strength for male planets is one unit by decrease. For the other planets, [that is], the female planets, the strength is one unit from the seventh up to the end of nine [signs]. On the other side, [that is], from the tenth to the end of the twelfth, the strength should be understood to be one unit by decrease: that is meant. This concludes the strength by time.

\subsubsection{Strength by Nature}

Next, strength by nature; and the strength by nature is described in the Tājikapradīpa:

One seventh of a unit is the strength of Saturn; that of Mars, Mercury, Jupiter, Venus, the moon and the sun is the same multiplied by two and so on, [respectively]. ${ }^{52}$

This concludes the strength by nature.

\subsubsection{Strength by Motion}

Next, strength by motion. Samarasiṃha [says in the Tājikaśāstra]:

[A planet] slow in motion, not swift in motion, not retrograde, free from malefic aspects, not joined to malefics, joined to [or] aspected by benefics, having risen [heliacally], is strong; also, in one degree with the sun ...53

53 The quotation from Samarasiṃha ends a quarter into a stanza. Viśvanātha, quoting the same verse in his commentary on Samjñātantra 2.69, supplies the next quarter: 'or in a fixed sign: then, too, they are strong'. The doctrine that a planet is strong when slow in motion agrees with Indian tradition but not with Greek or Perso-Arabic ones, which consider swiftness a strength; possibly Samarasimpha misunderstood his sources. Conversely, the doctrine that a planet is strong when conjunct the sun within one degree known as being 'synodic' or, later, 'in the heart' of the sun - is in line with Greek and Perso-Arabic traditions but contrasts with pre-Islamic Indian astrology, where this exception to the general principle of combustion is unknown (as demonstrated by Viśvanātha; cf. note 55). See Gansten 2018. 
etat spașțam uktaṃ tājikamuktāvalyām |

\section{dviguṇāṃśā rūponā vīryam athārkāmśagānāṃ ca| śubhasamaliptasya balaṃ krūrāsahitasya rūpaṃ syāt | mārgodayārdhabhāgasthitasya vāśighragasya madhyagateh || iti |}

atra sūryo yadrāśinavāṃśe tasminn eva navāṃśe sthitasya grahasya bhāgādyaṃ dviguṇaṃ șașțityaktam avaśeșaṃ balaṃ bhavati ||

atha śubhagraheṇa samānaliptasya șaștịkalā balam | nyūnādhikatve tu dvayor antaram triṃśadamiśanyūnaṃ vidheyam | tadaṃśā dvigunā balam | atra śubhasamalipto yadā krūragrahasahito bhavati tadā na balam ity api jñeyam ||

atha grahasya mārgaprārambhadine udayadine ca balopacayah | atha grahamārgadinam ārabhya vakraparyantạ̣ tathodayadivasam ārabhyāstaparyantaṃ yā dinasaṃkhyā tadardhaṃ vidhāya tāvatsaṃkhye 'hni șașțikalātmakaṃ balam | vakradine astadine ca balaṃ śūnyam antare 'nupātạ̣ | yadi madhyadinaih pūrṇaṃ śubhabalaṃ labhyate tadā mārgadinād gatair gamyair vā divasais tathā grahodayadinād gatair gamyair vā divasaị̣ kim iti | athodayāstavakramārgadinānāṃ jñānaṃ sugamopāyena madgurucaraṇaị̣ siddhāntacintāmaṇāv uktam |

2 rūponā] rūpona K T M || athārkāṃśa] athākaṃśi N G a.c. || ca] cā T 3 śubhasamaliptasya] śubham aliptasya B || krūrā-] krūra- T 4 -ārdhabhāga-] -ārdhaṃ bhāgo B N G || vāśīghragasya] 'vāśīghragamya B G; 'vāśāghragamya N 6 tyaktam] śeșam G p.c.; bhaktam K T M 8 triṃśadaṃśa] tiṃśa N a.c.; triṃśa N p.c. \| aṃśā] aṃśād M \|| dviguṇā] dviguṇạ̣ K T M 11-12 mārga ... graha] om. K T M 16 vā̄] yā N G 17 mad] śrīmad G p.c.

2-4 dvigunāṃśā ... gateh] TM 47-48

4 gateh] B inserts a character of uncertain meaning in the middle of this word.

54 'The middle part of its direct motion' means the midpoint between the time when a planet previously resumed direct motion and the time at which it will turn retrograde. 'The middle part of its [heliacal] rising' similarly means the midpoint between the time when the planet last became visible after leaving its conjunction with the sun and the time when it will last be visible before its next conjunction. For the superior planets, the latter position (here considered strong) will necessarily coincide with their retrograde motion (here considered weak), leading to contradiction. This is a partial and less sophisticated version of the Greek and Perso-Arabic doctrines of apparent planetary cycles in relation to the sun (see, e.g., Paul. Al. 14 and Abū Ma'shar Abbr. 2). 
This is described clearly in Täjikamuktāvali [47-48]:

Their degrees [and minutes] doubled and subtracted from one unit yield the strength of [planets] placed in the degree of the sun. The strength of [a planet] in the same minute of arc as a benefic, not joined to a malefic, is one unit, or of [a planet] occupying the middle part of its direct motion [or heliacal] rising, not moving swiftly, of middling motion. ${ }^{54}$

Here, in whatever sign and ninth-part the sun is [placed], the degrees and so on of a planet occupying that same ninth-part [should be] doubled and subtracted from sixty: the remainder is the strength [of that planet]. ${ }^{55}$

Next, the strength of [a planet] in the same minute of arc as a benefic planet is sixty points. But if [its longitude] is smaller or greater, the distance between the two should be subtracted from thirty. Those degrees doubled are the strength [of the planet]. Concerning this, it should also be understood that when [the planet] in the same minute of arc as a benefic is [also] joined to a malefic, then it has no strength.

Next, the strength of a planet increases from the day when it commences its direct motion and from the day when it rises [heliacally]. As many days as there are, then, from the day of the planet's [assuming] direct motion up to [the beginning of] retrogression, and likewise from the day of [heliacal] rising up to setting, dividing them by half, after that number of days the strength amounts to sixty points. On the day of retrogression or setting, the strength is nil; in the interval, [the strength is calculated by] proportion: if full benefic strength is obtained by the days [up to] the middle, then how much [is obtained] by the days elapsed from the day of [the beginning of] direct motion or remaining [before retrogression]; likewise, by the days elapsed from the day of the planet's [heliacal] rising or remaining [before setting]? Now, the knowledge of the days of [heliacal] rising, setting and [commencing] retrograde and direct motion by an easy method is described by my venerable teacher in the Siddhāntacintāmaṇi:

Balabhadra here adopts a forced interpretation of Samarasiṃha's word bhäga (lit. 'part, portion', typically used in the sense of 'degree' in astrological contexts) as 'ninth-part'. A different solution to the problem posed by Samarasimha's statement is proposed by Viśvanātha, who correctly notes that even a planet conjunct the sun within a ninthpart would be combust or invisible, and therefore suggests the (mistaken) emendation 'not in one degree with the sun'. 
pūrvāstatah paścima udgamo 'smād vakram tato 'stah para udgamah prāk| mārgī purāstāt khalu dantadantair vedair nrpair vedaradair budhaḥ syāt || bhrgoh sārdhadvimāsāșțamāsais tryaśvidinaị kramāt | navabhis tryaśvidivasair māsair aștamitais tathā $\|$ bhaumāstād udayas tasmād vakram tadanu mārgatā $\mid$ tato 'sta evam kramato vedakāșthādvipañktibhị $\|$ māsair bhuvā sānghrivedair yugaih sānghriyugair guroḥ| śaneḥ sānghribhuvā rāmair vedaị̣ sārdhaiś ca vahnibhị \|

ity udayāstādidinajñānam ||

\begin{tabular}{lll}
\hline & budhạ̣ & śukrạ̣ \\
\hline pūrvāstāt paścimodayam & dināni 32 & dināni 75 \\
paścimodayād vakram & dināni 32 & dināni 240 \\
vakrāt paścimāstam & dināni 4 & dināni 23 \\
paścimāstāt prāgudayam & dināni 16 & dināni 9 \\
prāgudayān mārgam & dināni 4 & dināni 23 \\
mārgāt pūrvāstam & dināni 32 & dināni 240
\end{tabular}

\section{manggalạ̣ bṛhaspatị̣ śanị}

\begin{tabular}{llll}
\hline astād udayam & 4 & 1 & 1730 \\
udayād vakram & 10 & 4730 & 3 \\
vakrān mārgam & 2 & 4 & 4 \\
mārgād astam & 10 & 4730 & 315 \\
\hline
\end{tabular}

1 'smād] stād B N; 'stād G 2 purāstāt] purostī B N G; purosto K T 3 māsāṣta] māsyașța B N G K T \| tryaśvi] tryasthi B N; trasthi G a.c.; traśvi G p.c. 5 bhaumāstād] māstād N G \| tadanu] datadanu N 6 kāṣțhā] kāșțho K T M 7 bhuvā] bhurvā T 10 śukraḥ] bhṛgu G 11 pūrvāstāt paścimodayam] pūrvāstāścimedayah K; pūrvāstāścimodayạ̣ T; pūrvāstāt paścime $^{\circ} \mathrm{M} \|$ 32] 22 B 13 paścimāstam] paścimo 'stam K T M \|| 4] 3 B G 14 udayam] udayaḥ K T M 15 mārgam] mārgah K T M \| 4] 3 B G 17 bṛhaspatiḥ] gu G 18 udayam ] udayah B K T K || 17 30] 1 B; 1|8G 1947 30] 48 B G 21 astam] astaḥ M \| 473 30 48 B G

10 budhah] The following table is omitted by N. K T M abbreviate some words. 17 mangalah] The following table is omitted by $\mathrm{N}$. The remaining text witnesses abbreviate some words. 
After setting in the east there is rising in the west; thereafter retrogression; then setting; next, rising in the east; [then] Mercury is direct until setting, for thirty-two, thirty-two, four, sixteen, four and thirty-two [days, respectively]. For Venus, [the same is true] for two and a half months, eight months, twenty-three days, nine [days], twenty-three days, and eight months, in order. After the setting of Mars there is rising; thereafter retrogression; after that, direct motion; then setting, in that order, for four, ten, two and ten [months, respectively]. For Jupiter, [the same is true] for one month, four and a quarter, four, and four and a quarter, [respectively]; for Saturn, for one and a quarter, three, four, and three and a half [months, respectively].

This concludes the knowledge of days of rising and setting and so forth.

\begin{tabular}{lll}
\hline & Mercury & Venus \\
\hline Eastern setting to western rising & 32 days & 75 days \\
Western rising to retrogression & 32 days & 240 days \\
Retrogression to western setting & 4 days & 23 days \\
Western setting to eastern rising & 16 days & 9 days \\
Eastern rising to direct motion & 4 days & 23 days \\
Direct motion to eastern setting & 32 days & 240 days \\
\hline
\end{tabular}

\begin{tabular}{llll}
\hline & Mars & Jupiter & Saturn \\
\hline Setting to rising & 4 & 1 & $1 ; 7,30$ \\
Rising to retrogression & 10 & $4 ; 7,30$ & 3 \\
Retrogression to direct motion & 2 & 4 & 4 \\
Direct motion to setting & 10 & $4 ; 7,30$ & $3 ; 15$ \\
\hline
\end{tabular}


atha grahagatibalam | tatra aśīghrasya ko 'rthah | mandagater madhyagatinyūnaspaștagater grahasya sabalatvam | tathā madhyamagater madhyamagatitulyaspaștagater grahasya ca sabalatvam | madhyamagatito 'dhikaspaștagater grahasya balābhāvo jñeyah | atra bhaumasya gatitulyāḥ kalā dviguṇā balaṃ bhavati | budhasya gatikalāḥ șạ̣guṇā ekonāsiîtihṛtā balaṃ bhavati | guror dvādaśaguṇāh śukrasya svatryaṃśarahitāḥ śanes triṃśadguṇā iti | mathitārtho gurusampradāyāj jñeyah | iti ceșțābalam ||

atha dṛbalaṃ tatraiva |

lagnaṃ paśyati yāvat tāvat tasya grahasya vīryaṃ syāt |

śubhadrștasya ca pāpagrahaturyadŕśonitasya pādonam ||

atra yasya grahasya yāvatī lagnasyopari dṛștị tāvad eva tasya dṛgbalam | atha śubhadṛșțasya grahasya yāvatī śubhadṛșțị sā pādonā balaṃ syāt | paraṃ tu krūraturyadṛștirahito graho 'pekșitah | tatsambhave na balam iti vīkșate lagnam sabalı̄ iti samarasiṃhạ̣ | iti dṛgbalam ||

3 spașṭagater] spagater N G 6 trimśadguṇā] trimśaṇāḥ T $\quad 9$ tāvat] vat K $\|$ syāt] syāt tā K 12 yāvatī] yāvatā B N G 13 tu] om. B N G

15 balānayanam] $\mathrm{N}$ inserts a character of uncertain meaning in the latter part of this word.

$5^{6}$ Although the work last quoted was, properly speaking, Rāma Daivajña's Siddhāntacintāmaṇi, Balabhadra is probably referring back to Samarasiṃha's Tājikaśāstra, which serves as his starting point for the discussion of the 'sixfold strength'. 
Next, the planets' strength by [daily] motion. Concerning this, what does 'not swift' mean? A planet of slow motion, [that is], whose true motion is less than its mean motion, is strong; so also, a planet of middling motion, [that is], whose true motion equals its mean motion, is strong. [But] a planet whose true motion exceeds its mean motion should be understood to be bereft of strength. Here, twice the minutes of arc corresponding to the [daily] motion of Mars is its strength; the minutes of arc of Mercury's motion multiplied by six and divided by seventy-nine is its strength; for Jupiter, [the strength is the minutes of arc] multiplied by twelve; for Venus, [its minutes of arc] less by one third; for Saturn, [the minutes of arc] multiplied by thirty. The substance [of these calculations] should be learnt from the tradition of one's teacher. This concludes the strength by motion.

\subsubsection{Strength by Aspect}

Next, strength by aspect [is described] in the same [work]:56

As much as a planet aspects the ascendant, that much strength does it have. And [the strength] of [a planet] aspected by benefics [and] free from the fourth-[sign] aspect of a malefic planet is a quarter less.

Here, whichever planet aspects the ascendant by any amount, that is the amount of its aspect strength. Further, the strength of a planet aspected by a benefic is a quarter less than the amount of the benefic aspect; however, [only] a planet free from the fourth-[sign] aspect of a malefic is intended, [for] if that [aspect] is present, there is no strength: hence Samarasimha says [in the Tãjikaśāstra], 'A strong [planet] aspects the ascendant'.57 This concludes the strength by aspect.

\subsection{Other Calculations of Strength}

Next, the calculation of strength for the sahamas of the twelve houses beginning with the ascendant is described in [Tājika]muktāvali [61-62]:58

57 This exact phrase is not quoted elsewhere in the text.

$5^{8}$ Balabhadra's claim that these two stanzas refer to sahamas or lots is supported by colophons in Mss of the Täjikamuktāvali, though not by the stanzas themselves, which do not contain the word sahama. The word used is sadman 'dwelling, abode', which in a Tajjika context is sometimes used as a synonym of sahama, but which might also refer to the twelve horoscopic houses themselves, giving a less tortuous reading of the Sanskrit. I have nevertheless translated sadman as 'lot' in the following quotation. 
tanvādikānām iha sadmanām tu patyur balaṃ caiva balaṃ pradișțam | svanāthajīvajñadrśā sametaṃ nṛbheșu rūpānvitam āpyabheșu \| catuṣpadākhyeșv api cārdhayuktaṃ na kīțabhe kiṃcana yojanīyam | śubhāśubhavyomagadṛviyogayugāṃśayuktonam atisphuțạ̣ syāt || iti |

viśeșam āha vāmanaḥ |

svasvasvāmibalatvena jñeyo rāśir balādhikaḥ| jōvajñayukto drșto vā svasvasvāmiyutekșitạ̣\| prșțhodayāh karkimrgadhanurmeșavrṣāa amī| śeșā śirṣodayā jñeyā mīnas tūbhayatah smṛtah \| śīṣodayā dinabalāh śeșā rātribalāh smṛtāh | nrrāśayo 'tha lagnasthā daśamasthāś catuspadāḥ || vrścikaḥ saptamasthāne caturthe jalarāśayaḥ| saṃdhyāyāṃ vrściko rāśir divase nararāśayaḥ\| rātrau balậ̣hyāḥ śeṣāḥ syur ittham rāśibalam smṛtam | iti rāśibalam proktam purāṇācāryasammatam \|

atrāṣṭadhā grahāṇāṃ balaphalam uktạ̣ padmanābhena | atra ekaikaṃ prati sārdhaṃ viṃśopakaṃ balaṃ jñeyam | sampūrṇaṃ balạ̣ șaḍviṃśopakātmakam | madhyamaṃ balaṃ triviṃsopakātmakam | tryūnam adhamabalaṃ jñeyam | tad yathā |

śūnye hānis tathā kleśo ardhe śoko mahad bhayam | vaimanasyam tathodvego rūpe proktam idam phalam \| sārdharūpe tanoḥ pị̣̂a dvābhyām duḥham sukhaṃ samam |

3 yuktaṃ] muktam G p.c. $\quad 4$ ati] iti K $\quad 11$ lagna] la K || -sthā] -sthād B N 16 atrāṣta-adhā] athāșțadhā K T M 17 sārdhaṃ] sāddhīṃ N || balaṃ¹] om. B N G a.c. 18-19 tryūnam adhama] scripsi; tryūnamadhyama B G p.c.; anamadhyama N G a.c.; tryūnam madhyama $\mathrm{K}$ T M 20 kleśo] hy add. K T M $\|$ ardhe] arghye N; ardhye G 21 vaimanasyam ] vainamasyam $\mathrm{G}$

1-4 tanvādikānām ... syāt] TM 61-62 
And the strength of the lots of the [houses] here beginning with the ascendant is declared to be the strength of the ruler. ${ }^{59}$ Joined to the aspect of its ruler, Jupiter or Mercury, in human signs, it gets one unit [of strength]; in watery and quadrupedal signs, it gets half; in Scorpio, it gets nothing. [This strength] becomes very exact when made greater or less by a quarter [of the strength] derived from the aspect [or] separation of benefic or malefic planets.

Vāmana states a special rule:

According to the strength of its own ruler, a sign should be understood to be strong [when] joined to or aspected by Jupiter or Mercury [or] joined to or aspected by its own ruler. Cancer, Capricorn, Sagittarius, Aries and Taurus: these rise with their backs. The rest rise with their heads; but Pisces is known both ways. [The signs] rising with their heads are strong by day; the rest are known as strong by night. And human signs [are strong] in the ascendant, quadrupedal [signs] in the tenth, Scorpio in the seventh place, and watery signs in the fourth. The sign of Scorpio is strong at twilight, human signs in the day, the rest at night: this is known as the strength of the signs. Thus the strength of the signs as approved by the ancient teachers has been described.

Concerning this, the eightfold result of the strength of the planets is described by Padmanābha. Here, for each [result], the strength should be understood to increase by half a point. The maximum strength comprises six points; middling strength comprises three points; less than three should be understood to be poor strength, as follows:

When [the strength] is nil, there is loss and suffering; when half [a point], grief and great danger; dejection and anxiety are said to result when it is one point; when a point and a half, bodily pain; when two, happiness and unhappiness in equal measure; when two and a half,

This half-stanza reads differently in independent witnesses of the Tãjikamuktāvali: 'For the lots of [the houses] (or: For the places) here beginning with the ascendant, the strength is that arising from the aspect kataya of its ruler.' The non-Sanskrit word kataya/kataya (possibly an instrumental inflection of *katā) might conceivably be a variant of kuttha 'strength' (Arabic quwwa), which would fit the context. In any case, either Balabhadra or some intervening copyist appears to have smoothed out the troublesome phrase. 
sārdhadvābhyām sukhāvāptis tribhir bhogaḥ sukhaṃ dhanam |

sārdhatraye sarvasiddhiś caturbhị̣ sarvato yaśạ̣ || iti |

nirbalagrahalakṣaṇaṃ tu viśeșataś candrasya duruḥhhayoge vakṣyamāne viśadībhavișyatīit | nașțabalānāṃ sūryādīnāṃ phalam uktaṃ tejaḥsiṃhena |

tvagdrșțirukparibhavādi ravau vinaște

'bje 'rthakșayo 'ratirujo 'vanije laghutvam |

jñe jñānahānir anuvrttyapapunyatejye

śukre tv abhogasukhatānugabhịh śanau ca || iti |

aṇuvṛttir alpavṛttir apapuṇatā punyarāhityam anugabhīh svasevakād bhayam | atha balaprasangāa ișțakașțavicāro likhyate | tatprayojanam uktam 10 ratnāvalyām |

tājikoktaphalādeśaḥ prakartum śakyate yataḥ| ișțakaștaphalajñānān nirṇayas tad athocyate \| svocce mitroccago mārgī suhṛtsaumyāvalokitaḥ| uditaḥ saumyacārì ca tritrikoṇāyago 'thavā vargottame mitravarge svagehe süryabhägagaḥ| mūsariḥpo muthaśilạ̣ saumyaih saumyāntago yutạ || evam balayutah khețo jñeyah șoḍaśadhā budhaih | nīce śatrūccago vakrì ripupāpāvalokitạ $\|$ astago yāmyabhāgastho lagnād riḥphārișu sthitaḥ |

\footnotetext{
1 bhogaḥ] bhogo B N G; bhāgaḥ M 3-4 nirbala ... bhavișyatīti] om. K T M 4 balānāṃ] calānāṃ M $\quad 6$ 'bje] jjve N 7 vṛttyapa] vṛtthaya B; vṛtyaya N G K; kṛtyaya T 9 vṛttir²] vṛtyaitir N G || apapuṇyatā] ayapunyatā B K || sevakād] śevaka T 10 bala] om. KT M 12 śakyate] kyaśete $\mathrm{N}$

$5^{-8}$ tvag ... ca] DA 228

2 iti] From the context, one stanza appears to be missing. G notes in a different hand in the margin: truța.
} 
attainment of happiness; when three, pleasure, happiness and riches; when three and a half, success in everything; when four, renown everywhere. ${ }^{60}$

The detailed definition of a powerless planet will become clear in the discussion of the moon's duruhpha configuration below. The results of the sun and other planets being powerless are described by Tejạsimịha [in Daivajñälamkrrti 228]:

Diseases of the skin and eyes, humiliation and so on [will result] when the sun is powerless; when it is the moon, loss of wealth, enmity and illnesses; ${ }^{61}$ when Mars, dishonour; when Mercury, loss of knowledge; when Jupiter, scant occupation and impiety; when Venus, want of happiness from pleasures; and when Saturn, peril from attendants.

'Scant occupation' [means] little occupation; 'impiety' [means] lack of piety; 'peril from attendants' [means] danger from one's servants. Next, as it is connected with strength, the judgement of [strength for] good and evil is written. Its purpose is described in the Ratnāvali:

Now the judgement according to the knowledge of good and evil results is described, by which it becomes possible to predict the results described by the Tājikas:

[1] In its own exaltation, [2] in the exaltation of a friend, [3] direct in motion, [4] aspected by a friend [5] or a benefic, [6] [heliacally] risen, [7] moving north [of the ecliptic] or [8] in the third, a trine, ${ }^{62}$ or the eleventh house, [9] in an optimal division, ${ }^{63}[10]$ in the division of a friend, [11] in its own domicile, [12] in the degree of the sun, [13] in a müsarihpha or [14] mutthaśila with benefics, [15] between benefics or [16] joined [by them]: such a planet should be understood by the wise to be strong in sixteen ways.

[1] In its fall, [2] in the exaltation of an enemy, [3] retrograde, [4] aspected by an enemy [5] or a malefic, [6] [heliacally] set, [7] occupy-

6o The results of $4^{1 / 2}, 5,5^{1 / 2}$ and 6 points appear to be missing.

61 Possibly the 'enmity and illnesses' should be read with Mars rather than the moon. Another possible reading is 'sexual illnesses'.

62 'A trine' in this context means the fifth or ninth house.

63 Vargottama is a part of a sign, particularly a ninth-part, corresponding to that same sign, e.g., the ninth-part of Aries in Aries. 
vargottamavihīno yah śatruvarge gṛe pica $\|$

sūryabhāgojjhitah krūrai rihpho muthaśilo 'pi ca |

pāpayukto madhyagato jñeyaḥ khețo balojjhitậ || iti |

atra śubhasthānage grahe śubhaphalaṃ rūpamitam sthāpyam | aśubhasthānage grahe aśubhaphalaṃ rūpamitạ̣ sthāpyam | punaḥ subhāśubhaphalayor antare kṛte sati yac chubham aśubham vā avaśisțam tad eva grahasya ișțaṃ kașțam vā phalaṃ daśāphalādiṣu jñeyam | etat spașțam uktam manitthena |

sarvatra kalpyaṃ prthag eva rūpaṃ phalam śubhākhyam phalanirnayāya | ihāpi rūpaṃ parikalpya sādhyam phalam ca kaștābhidham atra tajjñaị $\|$ prthaksthitasyāsya yad antarālam phalam tad evābhidham atra vedyam | daśädhike śreșthaphale ca pūrnam phalạ̣ daśone kathitạ̣ ca madhyam \| kaștāadhike pürnaśaśānkahine śubhe ca kaște daśato varișthe | kaștāt tathā kaștataram niruktạn phalaṃ daśāyām yavanaih purānạih || iti |

atha pañcavargebhya ișțakaștam uktaṃ tājikamuktāvalyām |

dalaṃ dalārdham ca tadardhakạ̣ ca

svakīyamitrārigrhe subham syāt |

tathaiva drkke 'ngalavas tadardham

tatkhandakam nandalave 'rkabhägah $\|$

tadardhakam taddalam eva trimśe

tithyamśakordhvam ca dalam tv athocce |

nakhāmśakordhvam ca dalam ca nīce

śūnyaṃ khavedāṃśanakhāṃśakau ca || iti |

2 bhāgojjhitaḥ] bhāgo 'hitaḥ G p.c.; bhāgobhitaḥ M \| krūrai] krūro B N G 3 balojjhitaḥ] 'valokita G p.c.; balobhita M 5 mitam] saṃmitam G $\quad 7-8$ spașțam uktam] spașțaktam K 19 śubham] svabhe K T M 20 dṛkke 'nga] dṛkkendra M 22 taddalam] tadbalam M \| eva] eka B 23 athocce] athoccai B N G; atho*aḥ T 25 nakhāṃśakau] nakhāṃśako $\mathrm{BN}$

9-16 sarvatra ... purāṇaih] VPh 15-18; cf. HS 40-41 18-25 dalam ... ca] TM 64-65

9 nirṇayāya] G notes in a different hand in the margin of folio $37^{\mathrm{v}}$ : truta 37 patre * Some text does appear to be lacking from the quotation as compared with independent witnesses of the VPh. 25 iti] Alone among the text witnesses, M (the latest) adds a table giving the preceding fractions in numerical format, numerators placed above denominators. That table has been omitted here as likely being a modern addition. 
ing a southerly degree [of latitude], [8] placed in the twelfth or sixth house from the ascendant, ${ }^{64}$ [9] without an optimal division, $[10]$ in an enemy's division [11] or domicile, [12] having left the degree of the sun, [13] in a rihpha or [14] mutthaśila with malefics, ${ }^{65}$ [15] joined to benefics or [16] placed between [them], a planet should be understood to be bereft of strength.

Here, one unit of good results should be entered when a planet occupies a good position, and one unit of evil results should be entered when a planet occupies an evil position. Then, after finding the difference between the good and evil results, the [strength for] good or evil that remains is the good or evil result of the planet, to be understood in [judging] the result of periods and so forth. This is described clearly by Manittha [in Varșaphala 15-18]:

One unit of the results called good should be given for each place in order to judge results. Having allotted these points, the wise should find the results called evil. The difference between these separate [figures] should be understood to be the [final] result. When the good result is greater than ten, [that] result is full; when it is less than ten, it is called middling; when the evil is greater [than the good] and the good is less than ten, or when the evil is more than ten, the result of the period is declared by the ancient Yavanas to be evil and very evil, [respectively].

Next, the [strength for] good and evil [arising] from the five dignities is described in Täjikamuktāvali [64-65]:

The [strength for] good in [a planet's] own domicile, that of a friend and that of an enemy is half [a point], half of one half, and half of that, [respectively]. In a decan, likewise, it is one sixth of a point, half of that, and half of that; in a ninth-part, it is one twelfth, half of that, and half of that; in a thirtieth-[part], it is one fifteenth, half, and so on; in exaltation, it is one twentieth, half, and so on; in fall, it is nil, one fortieth, and one twentieth.

64 All text witnesses share this reading, although the compound is in the plural rather than the dual, which would properly suggest at least three compounded items. The eighth house is typically listed with the sixth and twelfth.

65 From the context it would seem that rihpha is used here not in the standard sense, as a name for the twelfth house (from Greek pi $(\varphi \eta)$ ), but rather as a truncated form of müsariḥpha (from Arabic munșarif; cf. next chapter). 
etadūnaṃ yad vā sveștārātișu dvādaśāṃśā ityādyuktabalavibhāgāṃśam kașțaphalaṃ sādhyam | itīṣțakașțavicārah | atra kecana sāmānyenaiva așțadhā balaṃ kalpayanti | uktaṃ ca hillāje |

\section{samagatir udito yah saumyadrșto 'tha yuktah}

sa śubhamuthaśilì syāt saumyabhāve 'rkabhāge |

vicarati śubhamadhye cātivirryah pradiștah

kathitabalavirodhì hinavīryạ khagendrạ $\mid$

ubhayabalasamāse cāpy abhāve tayor $v \bar{a}$

vicaratiyadi khețo madhyaviryo munindraih || iti |

atra samagativirodhah śīghragatị̣ | uditavirodho 'stagah | evaṃ sarvatrāpi

jñeyam | atra pratyekaṃ sārdhaviṃśopakadvayamitam balaṃ jñeyam | athātra viśeșaphalajijñāsunā pūrvoktam șaḍvidham api balạ̣ vicāryam | tadabhāve sāmānyapañcavargībalaṃ vicāryam | tadabhāve 'py așțadhā balaṃ vicāryam iti siddhāntạ̣ ||

atha dvādaśavargīcakram | tatra vāmanaḥ |

1-242.16 -rātișu ... tanvā-] om. B N G a.c. 1 dvādaśāṃśā] dvādaśāṃkā G 3 hillāje] hillājena M 10 gatiḥ] scripsi; gati K T; gaty M 12 balaṃ] dhanaṃ G 14 siddhāntạ̣] rāddhāṃtah G

1 yad ... dvādaśāṃśā] TM 41

1-242.16 -rātiṣu ... tanvā-] In G the preceding phrase etadūnam yad vā sveșțādi has been crossed out, and a note in the margin reads trutah $37 \mid 5$. The omitted passages are supplied on a separate folio in a different hand. 15 cakram] At this point G adds the following stanza, near-identical to the previous quotation from Vāmana: sukhāvāptis tribhir bhogo yaśovṛ̂ddhị sukham dhanam || sārddhatraye sarvasiddhiś caturbhiḥ sarvato yaśa iti $\|$ 
The evil result should be found by subtracting these [values] from the allotted points of strength stated in [the quotation from Täjikamuktāvali $5^{1-52}$ above], beginning 'Or else, in [the scheme consisting only of the planet] itself, friends, and enemies, the twelfths of points'. This concludes the judgement of [strength for] good and evil. Concerning this, some consider the strength as an eightfold total; and Hillāja says:

The planet that is [1] of middling motion, [2] [heliacally] risen, [3] aspected or [4] joined to benefics, [5] in a benefic mutthaśila, [6] in a benefic house, [7] in the degree of the sun, and [8] placed between benefics is declared by the great sages to be exceedingly powerful; one that negates the strengths [just] described, to have little power; and, if the planet has a balance of both strengths [for good and evil], or in the absence of both, to be of middling power.

Here, the negation of middling motion is swift motion; the negation of [heliacally] risen is set: this is how all [the criteria] should be understood. On this matter, each [criterion of] strength should be understood to amount to two and a half points. The conclusion, then, is that anyone wishing to know the detailed results [of a planet] should consider the sixfold strength described above; failing that, one should consider the total strength of the five dignities; and failing even that, one should consider the eightfold strength.

\subsection{The Twelve Dignities}

Next, the scheme of twelve dignities. On that, Vāmana [says]: 
gṛhahorādreșkāṇāh pādāṃśah pañcāmnśașașthāṃśau |

saptāștanavadaśāmśā rudrāmśā dvādaśāmiśāś ca \|

bhaumaśukrajñacandrārkabudhaśukrāramantrinaḥ |

sauriḥ śanis tathā jìvo meșādīnām adhišvarāh $\|$

lagnārdham jāyate horā sarvalagneșu sarvadā |

ojarāśibhavārkendvoḥ same candrārkajā matā ||

meșādisarvarāsínām tribhāgeșu yathākramam |

ädyapañcanaveśānām dreșkānā bhanitā budhaih \|

ekadvitricaturtheșu lagnapādeșu ca kramāt |

svasvarāśyādikendreśāḥ pādāṃśanāyakā matāḥ \|

kujārkïjyabudhāh śukraḥ pañcamāmśsșu nāyakāḥ|

ojarāsișu yugmeșu grahā vyatyayataḥ smrtāh \|

meșādyā vișame rāśau samarāśau tulādikāḥ |

vijñeyā vibudhair evaṃ rāsișașțāṃnśanāyakāḥ \|

ojarāśau svarāśyādyāḥ same saptamarāśitah |

saptāmśanāyakāh sarve vijñeyā vibudhaih sphuțāh $\|$

meșādyāś cararāśīnām cāpādyāḥ sthirarāśș̣ |

dvisvabhāveșu siṃhādyā jñeyāś cāṣtāmśśanāyakāh ||

meșamrgatulākarkamukhāḥ syur navamāmśakāḥ|

meșakesaridhanvādirāsicakre vyavasthitāḥ \|

13 samarāśau] om. K 15 saptama] sapta T 19 meșamṛga] meṣo mṛas G || navamāṃśakāḥ] navabhāṃśakāḥ K

1 pādāṃśah ... șașṭhāṃśau] K T M agree on this unmetrical reading, one mora short.

66 Most of these divisions are either inherited from Hellenistic astrology or innovations of pre-Islamic Indian tradition. The horā (from Greek $\ddot{\omega} \rho \alpha$ 'hour', the average rising time of half a sign) represents a division by 2 . The division by 5 is a 'streamlined' form of terms (hadd/haddā, trimsśāmśa), while the division by 10 is found in classical Indian astrology but distributed among the planets by a different method. Only the divisions by 6,8 and 11 are unknown to both, as well as to Perso-Arabic sources. See Gansten 2018.

67 While the divisions of a sign are not dependent on the ascendant as such, the ascendant is often defined in Indian astrology according to the divisions in which it falls.

68 This is the classical Indian scheme of decan rulership rather than the Greek and PersoArabic one discussed in sections 2.5 and 2.6 above.

69 The angles are the first, fourth, seventh and tenth sign, counting inclusively - in other words, the signs distant from each other by multiples of $90^{\circ}$. 
Domicile, horā, decan, fourth-part, fifth-part, sixth-part, seventh[part], eighth-[part], ninth-[part], tenth-part, eleventh-part and twelfth-part [are the twelve dignities]. ${ }^{66}$

Mars, Venus, Mercury, the moon, the sun, Mercury, Venus, Mars, Jupiter, Saturn, Saturn and Jupiter are the [domicile] rulers of [the signs] beginning with Aries.

Half of the ascending sign is a horā. In all ascendants, always, they are considered to belong to the sun and moon, [respectively], in an odd sign; in an even sign, to the moon and sun. ${ }^{67}$

In all signs, beginning with Aries, the thirds are declared by the wise to be the decans of [the planets] ruling the first, fifth and ninth [signs from the current one], in order. ${ }^{68}$

In the first, second, third and fourth quarters from the ascendant [sign], the rulers of the fourth-parts are considered to be [the planets] ruling the angles from the sign in question. ${ }^{69}$

Mars, Saturn, Jupiter, Mercury and Venus are considered to be the rulers of the fifth-parts in the odd signs; in the even [signs], the planets are in the reverse order.

The rulers of the sixth-parts of a sign should be understood by the wise to begin from [the ruler of] Aries in an odd sign and from [the ruler of] Libra in an even sign..$^{70}$

The true rulers of the seventh-parts should all be understood by the wise to begin from the sign in question in an odd sign, and from the seventh sign [from it] in an even sign.

The rulers of the eighth-parts should be understood to begin with Aries in the movable signs, with Sagittarius in the fixed signs, and with Leo in [the signs] of dual nature.

The ninth-parts in the cycle of signs beginning with Aries, Leo and Sagittarius begin with Aries, Capricorn, Libra and Cancer. ${ }^{71}$

The wise know that the planets ruling the [first] tenth-parts in an ascendant [beginning with Aries] follow in the order [of the rulers of] Aries, Aquarius, Sagittarius, Libra, Leo and Gemini.

70 In other words, beginning from $\circ^{\circ}$ Aries, the 72 sixth-parts in the zodiac form 6 continuous cycles corresponding to the 12 zodiacal signs. The newly invented eighth-, tenth-, and eleventh-part divisions below follow the same pattern, as do the older seventhand ninth-parts.

71 That is, in Aries, Leo and Sagittarius, the first ninth-part belongs to Aries; in the signs immediately following these (namely, Taurus, Virgo and Capricorn), the first ninth-part belongs to Capricorn; etc. 
ajakumbhadhanustaulisimhayugmakramena tu| daśāmśanāyakā lagne grahān evaṃ vidur budhāḥ || meșaminaghațā nakracāpālitulakanyakāḥ | siṃhakarkațayugmokșādikā rudrāṃśanāyakāh \| svasvarāśyādikā jñeyā dvādaśāmsśakanāyakāḥ | evam lagne 'tra vijñeyā budhair dvādaśavargikā $\|$ sūryādīnām tu khețānām vīkssyā dvādaśavargikā | śubhā svamitrasaumyoccā nindyā nīcāripāpajā || evam phaladvayam vīkșya tad viśodhyam parasparam | taccheșam tatphalam jñeyam grahe dvādaśavargajam \| varge śubhädhike krūraḥ śubhạ̣ saumyo 'tiśobhanaḥ| nindyādhike śubhậ krūrạ̣ krūro 'tikrūratām vrajet || svagrhād yad graho datte tanvādibhāvajam phalam | nijavīryānumānena sthitam rāssiśabhāvajam \| ekaikarāśimadhyasthaṃ vijñeyam rāśimaṇdalam | tanvādibhāvarūpeña svagrhādikrameṇa ca \| tena dvādaśavargasya sūkșmasthūlaprabhedatạ | sthūlaṃ sūkșmaṃ phalaṃjñeyaṃ grahānām sarvabhāvajam || iti |

atraikaikarāśimadhyastham ity anena tanvādisarvabhāvānāṃ dvādaśavargikā vidheyāḥ | tasmād bhāvānāṃ sthūlasūkṣmaphalavicāraḥ kārya ity 20 arthaḥ | etat spașțam uktaṃ saṃjñātantre |

bhāveșu sarveșv api vargacakraṃ vilokya tattatphalam ühanīyam | iti |

dvādaśavargīcakre vimśśpakānayanam uktaṃ yogasudhānidhau |

4 yugmokṣādikā] scripsi; kāsokșādikā G; kyamokșādikā K; mokṣādikā T; kā mokṣādikā M 9 evaṃ pha-] om. T 10 vargajam] vargatah $G \quad 11$ śubhādhike] śubhādikaḥ $G$ \| śobhanaḥ] śobhanaṃ G 13 svagṛhād yad graho] svag̣̣hādyaṃ g̣̣ho G 17 tena] te ca K T M \| sūkșmasthūla] proktaṃ sthūla B N G a.c.; sthūlasūkșma K T M 18 sarva] rvasa N

22 bhāveșu ... ūhanīyam] ST 1.48 
The rulers of the eleventh-parts [in the signs reckoned from Aries] begin with [the rulers of] Aries, Pisces, Aquarius, Capricorn, Sagittarius, Scorpio, Libra, Virgo, Leo, Cancer, Gemini and Taurus, [respectively].

The rulers of the twelfth-parts should be understood to begin with [the ruler of] the respective sign. Thus should the twelve dignities in an ascendant be understood by the wise.

The twelve dignities of the sun and other planets are to be examined. [The divisions] arising from [the planet's] domicile, [the sign of] a friend, a benefic, or its exaltation are good; those arising from [the sign of] fall, an enemy, or a malefic are evil. Examining both [kinds of] results thus and subtracting the one from the other, the remainder should be understood to be that planet's resulting [strength] from the twelve dignities. In predominantly good divisions, [even] a malefic is good, and a benefic, exceedingly beneficent. If the evil [divisions] predominate, [even] a benefic is evil, and a malefic becomes exceedingly maleficent; for in accordance with its own strength [derived] from its domicile [and so forth] a planet gives the results of the houses beginning with the ascendant, residing [there and] produced by the ruler of the sign. ${ }^{72}$

The [entire] circle of signs should be understood as residing within every single sign, in the form of the houses beginning with the ascendant and in the order of [a planet's] own domicile and so forth. Therefore, in all houses, [both] the general and the detailed results of the planets should be understood, according to the general and detailed divisions of the twelve dignities.

Here, by [the statement] 'residing within every single sign' it is meant that the twelve dignities should be applied to all the houses, beginning with the ascendant. Therefore, [both] general and detailed judgement of the results of the houses should be made. This is stated clearly in Samjñätantra [1.48]:

Having examined the scheme of dignities for all the houses, one should infer the results of each.

The calculation of points [of strength] from the scheme of twelve dignities is described in [Täjika]yogasudhānidhi [4.10]:

72 The last sentence is syntactically unclear and its meaning somewhat tentative. 
śatam kalāh sve bhavanādike ca maitre tadardham ca ripau tadardham | tadaikyam abhrāngahṛd arkavargyāṃ vimissopakā vïryayutau bhavanti || iti |

atra kecana dvādaśavargīcakraṃ na kurvanti | pațhanti ca |

vāmanena grahānām yā proktā dvādaśavargikā |

purācāryair anuktatvāt kṛtrimā sā prakirtyate || iti |

etan na ramaṇiyam | yato 'tiprācīnācāryeṇa maṇitthena bhaumaḥ sito jñaḥ ityādiślokadaśakena dvādaśavargīcakram abhihitam | ata eva saṃjñātantre śrīmannīlakaṇthadaivajñair dvādaśavargīcakram uktam iti | iti dvādaśavargīcakram ||

atha grahāṇāṃ harṣabalam | tatra catvāri harṣadāni sthānāny uktāni tejaḥ- $\quad 10$ simhena |

nidhihutāsaș̣adekaśivātmajaryaya ināt prathamaṃ khalu harșadam | svagrham uccam atho dvitayam smrtam nikhilakhețagaṇeșu tṛtīyakam || atha dine nṛkhagasya tu yoșito bhavati rātrișu harșapadam tathā | udayatas tritayam tritayam kramād yuvatinrdyusadām ca caturthakam ||

4 yā] vā K T M 5 kṛtrimā] kṛttimā B G K; kṛtimā N \| iti] ti K; pi T 8 uktam] om. B N G a.c. 10 harșa ${ }^{1}$ ] varșa K M \| catvāri] om. B N G a.c. \| -dāni sthānāny] -dānāny B N G a.c.; sthānāny G p.c. 15 tritayam ${ }^{2}$ ] tṛtayaṃ K T $\|$ dyusadāṃ] dyuṣadāṃ K

1-2 śatam ... bhavanti] TYS 4.10 4-5 vāmanena ... prakīrtyate] TMṬ $1.2 \quad 6$ bhaumah ... jñah] $\mathrm{VPh}$ 51; HS $73 \quad$ 12-15 nidhi ... caturthakam] DA 7.1-2 
[A planet earns] a hundred points in its own domicile and so on; half in that of a friend; half again in [that of] an enemy. That sum divided by sixty makes up the total points of strength in the twelve dignities.

Concerning this, some do not use the scheme of twelve dignities, and they quote [Tājikamuktāvalițippaṇī 1.2]:

Because the twelve dignities of the planets set forth by Vāmana have not been described by the teachers of old, they are declared to be artificial.

[But] this is not agreeable, since the most ancient teacher Manittha sets forth the scheme of twelve dignities in the ten stanzas beginning 'Mars, Venus, Mercury' [Varșaphala 51-6o]. ${ }^{73}$ That is why the illustrious Nilakanțha Daivajña has described the scheme of twelve dignities in the Samjñätantra. This concludes the scheme of the twelve dignities.

\subsection{The Joys of the Planets}

Next, the strength of joy of the planets. On that matter, the four places that give joy [to the planets] are described by Tejahsiṃha [in Daivajñālaṃkrti 7.1-2]:

[House] nine, three, six, one, eleven, five or twelve is the first [place] giving joy [to each of the planets counted] from the sun; [its] domicile and exaltation is considered the second, among all the planets; next, the third place of joy is in the day for a male planet but at night for a female; and [the houses] by threes from the ascendant is the fourth for female and male planets in order.

73 Manittha or (Pseudo)-Manetho is indeed an ancient astrological authority mentioned by name by early Sanskrit authors (see, e.g., Brhajjātaka 7.1); for the actual ancient work on astrology ascribed to Manetho, see Lopilato 1998. The Varșaphala ascribed to 'Manittha' is, however, probably no older than the fifteenth century; see Gansten 2018. 
atra samarasiṃhena dvitīyakam harșapadam sarveșām nijagṛaṃ bhavati ity anena ślokārdhena svag̣̣ham eva harṣasthānam uktạ̣ na tu svoccam iti jñeyam | atra viṃśopakā uktāḥ paddhatibhūṣaṇe |

\section{harșānvitā harșapade pañca vimsśopakā matāh |}

harṣasthānacatuṣkasthaḥ khețah syāt pūrṇaharșitaḥ || iti |

atha samarasiṃhaṭikāyāṃ tukajyotirvidbhir ekaikaharṣasthāne rūpamitaṃ balam uktam | tatrāpi navamādisthāneșu lagnāt tritribheṣu ca pūrvoktayuktyā grahāṇāṃ bhāvaphalam eva balam | svag̣̣hoccabalạ̣ tu

rāśyante paramoccam tu procur grahavido janāḥ|

rāśyante pūrṇaphaladạ̣ svagrham ca tathā viduh \|

iti jīrṇatājikavacanāt svag̣̣hasvoccasthagrahasyāṃśādikaṃ dviguṇaṃ svagṛhasvoccabalaṃ bhavati | dinarātribalaṃ tu pūrvoktạ̣ grahadinabalam eva | punar grahāṇām viśeșabale prathamaharṣabalaṃ dinarātribalaṃ ca yojitam eva | ato harșasthānadvayabalaṃ viśeșabaleșu yojyam iti tattvam | sarveșām balānām aikyam sphuṭabalaṃ bhavati | sphuṭabalenaiva varșeśaphalaṃ daśāphalādikaṃ ca jñeyam iti vimalam | prathamaharșabale 'dhikasthānāni keșāṃcid grahāṇām uktāni praśnavaiṣnave |

karma bandhu dhanam cendos turyam jñasyodayaṃ raveh | dyūnam bhaumasya dharmarkṣaṃ śaneh prāhuḥ svaharṣadam || iti |

yādavena tu pañca harṣasthānāny uktāni |

\footnotetext{
1 harṣapadaṃ ... nijag̣̣haṃ] scripsi; nijagṛhaṃ sarveșāṃ harṣapadaṃ B N K T M; nijagraham sarveșāṃ harșapadaṃ $\mathrm{G} \quad 4$ pade] padaṃ N || pañca] ca N $\quad 7-8$ pūrvokta] pūrvocca $\mathrm{B}$ N G 8 balam] phalam N G 12 gṛhasvocca] gṛhococca N; gṛhe cocca G 17 'dhika] harșa add. K T M 18 bandhu] bandha B N \| cendos] cendvos B N G a.c. \|| jñasyodayaṃ] jñasthodayaṃ B N G a.c.; tasyodayam G p.c. 19 sva] sa K T M

4-5 harșānvitā ... harșitah] PBh 20 18-19 karma ... harṣadam] PV 2.30

1 harṣapadam ... nijagṛham] The unmetrical word order supported by all text witnesses suggests an error early in the transmission of the text, possibly even originating with Balabhadra. Restoring the metre does not change the meaning but does make for a somewhat more natural word order.
} 
Concerning this, it is to be understood from this half-stanza [in the Tãjikaśástra] by Samarasimha - 'The second place of joy for all [planets] is their own domicile' - that only [a planet's] domicile is a place of joy, and not its exaltation. The points for this are described in Paddhatibhūsana [20]:

In a place of joy, the points endowed with joy are considered to be five. A planet occupying [all] four places of joy rejoices fully.

Now, in his commentary on [the Tājikaśāstra by] Samarasiṃha, Tuka Jyotirvid assigns one unit of strength to each place of joy. Among them, in the ninth and other houses and in the places by threes from the ascendant, the [numerical] house result itself is the strength of the planets according to the reasoning described above. But [regarding] the strength from domicile and exaltation, when a planet occupies its domicile or its exaltation, its degrees and so on doubled yield its strength of domicile or exaltation, according to the statement of the Jirnatäjika:

The knowers of the planets say that the maximum exaltation is at the end of the sign; and they likewise know the domicile to give full results at the end of the sign.

Now, the strength of day or night is only the planets' strength of day described above; and [that] strength of day or night is itself applied again [as] the first strength of joy in [the calculation of] the detailed strengths of the planets. Thus, the truth of the matter is that the strength of two places of joy should be added to the detailed strengths. The total of all [these] strengths is the definitive strength, and it is from the definitive strength that the result of the ruler of the year, the result of periods and so forth should be understood. Thus [everything] is clear. Concerning the first strength of joy, additional places are described for some of the planets in Praśnavaiṣnava [2.30]:

The tenth, the fourth and the second for the moon, the fourth for Mercury, the ascendant for the sun, the seventh for Mars, and the ninth for Saturn are said to give them joy.

But Yādava describes five places of joy [in Tājikayogasudhānidhi 4.36-37]: 
nandāgnitarkenduśiveșvinākhyāḥ sūryādikānāṃ svagṛhaṃ nijoccam | strīpuṃkhagānām tanutas trayạ̣ ca niśādinam strīnarasaṃjñitānām \| puṃbhāni puṃsāṃ vanitāgṛhāṇi strīryomagānāṃ ca mudāspadāni| harșāspadeșv abdhiviśopakāṃś ca prthak prthak pañcasu saṃvadanti ||

iti śrīdaivajñavaryapaṇ̣itadāmodarātmajabalabhadraviracite hāyanaratne 5 dṛșțisāngabaleșțakașțādyānayanādhikāro dvitīyaḥ ||2||

1 g̣̣haṃ] gṛhān K $\quad 2$ strīpuṃ] scripsi; pumstrī B N G K T M 3 mudāspadāni] dāspadāni K; yadāspadāni TM 5 varya] vargya K || paṇḍita] ṇ̣̣itaT 6 baleșțakașțādy] baleștakādy $\mathrm{N}$

1-3 nandāgni ... āspadāni] TYS 4.36-37 4 harṣā- ... saṃvadanti] TYS 4.38

2 stripum] This emendation, required by the sense of the passage, is supported by MS TYS 1 . The error present in all text witnesses again suggests an early error. 
[1] [Houses] nine, three, six, one, eleven, five and twelve, [respectively], for the [planets] beginning with the sun; [2] one's own domicile and exaltation; [3] the [groups of] three [houses] from the ascendant for female and male planets, [respectively]; [4] night and day for the [planets] known as female and male, [respectively]; and [5] male signs for the male planets, female signs for the female planets, are the places of joy. To each of the five places of joy they assign four points.

In the Hāyanaratna composed by Balabhadra, son of the learned Dāmodara, foremost of astrologers, this concludes the second topic: the calculation of the aspects, the strength with its subdivisions, good and evil, and so forth. 